\title{
Synthetic route of trithiolato-bridged dinuclear arene ruthenium(II) complexes $\left[\left(\eta^{6}-p-\mathrm{MeC}_{6} \mathrm{H}_{4} \mathrm{Pr}^{i}\right)_{2} \mathrm{Ru}_{2}\left(\mu_{2}-\mathrm{SR}\right)_{3}\right]+$
}

\author{
Hedvika Primasová ${ }^{1 \#}$, Silviya Ninova ${ }^{1}{ }^{2 \#}$, Ulrich Aschauer $^{1 *}$, Julien Furrer $^{1 *}$ \\ 1 Departement für Chemie und Biochemie, Universität Bern, Freiestrasse 3, CH-3012 Bern, Switzerland \\ 2 Department of Chemistry and Physics of Materials, Paris-Lodron Universität Salzburg, Jakob-Haringer-Strasse 2a, A-5020 \\ Salzburg, Austria \\ \# both authors contributed equally to this work
}

\begin{abstract}
Several dinuclear trithiophenolato-bridged arene ruthenium complexes $\left[\left(\eta^{6}-p-\mathrm{MeC}_{6} \mathrm{H}_{4} \mathrm{Pr}^{\mathrm{i}}\right)_{2} \mathrm{Ru}_{2}\left(\mu_{2}-\mathrm{SC}_{6} \mathrm{H}_{4}-\mathrm{R}\right)_{3}\right]^{+}$could so far only be obtained with moderate yields using the synthetic route established in the early $2000 \mathrm{~s}$. With much less reactive aliphatic thiols or with bulky thiols, the reactions become even less efficient and the desired trithiolato complexes are obtained either only with bad yields or not at all. We employ density functional theory (DFT) calculations to gain a fundamental understanding of the reaction mechanisms leading to the formation of trithiolato complexes starting from the dichloro( $p$-cymene)ruthenium(II) dimer $\left[\left(\eta^{6}-p\right.\right.$ $\left.\left.\mathrm{MeC}_{6} \mathrm{H}_{4} \mathrm{Pr}^{\mathrm{i}}\right) \mathrm{Ru}\left(\mu_{2}-\mathrm{Cl}\right) \mathrm{Cl}\right]_{2}$. The results of this DFT study enable us to rationalize experimental results and allow us, via a modified synthetic route, to synthesize the previously unreported and hitherto considered as unrealistic trithiolato complex $\left[\left(\eta^{6}-p-\right.\right.$ $\left.\left.\mathrm{MeC}_{6} \mathrm{H}_{4} \mathrm{Pr}^{\mathrm{i}}\right)_{2} \mathrm{Ru}_{2}\left(\mu_{2}-\mathrm{SC}_{6} \mathrm{H}_{11}\right)_{3}\right]^{+}$. Our DFT study opens possibilities for the synthesis of so far inaccessible thiolato-bridged dinuclear arene ruthenium(II) complexes but more generally also the synthesis of other thiolato-bridged dinuclear group 8 and 9 metal complexes could be reexamined.
\end{abstract}

\section{INTRODUCTION}

Dinuclear tris(thiolato)-bridged arene complexes are typically obtained from the reaction of the precursor $\left[(\right.$ arene $) \mathrm{MCl}\left(\mu_{2^{-}}\right.$ $\mathrm{Cl})_{2} \mathrm{M}($ arene $\left.) \mathrm{Cl}\right] \mathrm{M}=\mathrm{Fe}, \mathrm{Ru}, \mathrm{Rh}$, Os, Ir with thiolate compounds and represent an interesting class of organometallic compounds. Iron complexes serve as carbon-halogen bond activation reagents, and carbon-halogen bond-cleavage agents, ${ }^{1-4}$ while osmium ${ }^{5}$, iridium, rhodium ${ }^{6-12}$ and especially ruthenium complexes ${ }^{13-25}$ have in vitro antiproliferative activity against cancer cell lines and several protozoan parasites. Tris(thiolato)bridged dimolybdenum complexes are also readily available but are synthesized using other strategies such as the direct oxidation of low-valence carbonyl precursors or reductive process from higher-valence derivatives, ${ }^{26-28}$ which will not be discussed here.

It is interesting to note that arene ruthenium(II) complexes were first obtained fortuitously about fifty years ago by Winkhaus and Singer and subsequently Zelonka and Baird. ${ }^{29-32}$ Only years later, these dimeric arene-ruthenium dichloride complexes $\left[\left(\eta^{6-}\right.\right.$ arene $\left.) \mathrm{Ru}\left(\mu_{2}-\mathrm{Cl}\right) \mathrm{Cl}\right]_{2}$ were found to react with thiols to give cationic trithiolato complexes of the type $\left[\left(\eta^{6} \text {-arene }\right)_{2} \mathrm{Ru}_{2}\left(\mu_{2^{-}}\right.\right.$ $\left.\mathrm{SR})_{3}\right]^{+}$, the first examples being the hexamethylbenzene derivative $\left[\left(\eta^{6}-\mathrm{C}_{6} \mathrm{Me}_{6}\right)_{2} \mathrm{Ru}_{2}\left(\mu_{2}-\mathrm{SPh}\right)_{3}\right]^{+}$reported by Rakowski DuBois and coworkers ${ }^{33}$ and the $p$-cymene derivative $\left[\left(\eta^{6}-p\right.\right.$ $\left.\left.\mathrm{MeC}_{6} \mathrm{H}_{4} \mathrm{Pr}^{i}\right)_{2} \mathrm{Ru}_{2}\left(\mu_{2}-\mathrm{SPh}\right)_{3}\right]^{+}$reported by Nakamura and coworkers, both of which contain three thiophenolato bridges. ${ }^{34}$ Over the last fifteen years, the series of dinuclear trithiolato bridged arene ruthenium complexes was extended, including complexes of the general formula $\left[\left(\eta^{6}-p-\mathrm{MeC}_{6} \mathrm{H}_{4} \mathrm{Pr}^{i}\right)_{2} \mathrm{Ru}_{2}\left(\mu_{2^{-}}\right.\right.$
$\left.\left.\mathrm{SC}_{6} \mathrm{H}_{4}-\mathrm{R}\right)_{3}\right]^{+}$and so-called mixed complexes of the general formula $\left[\left(\eta^{6}-p-\mathrm{MeC}_{6} \mathrm{H}_{4} \mathrm{Pr}^{i}\right)_{2} \mathrm{Ru}_{2}\left(\mu_{2}-\mathrm{SC}_{6} \mathrm{H}_{4}-\mathrm{R}^{1}\right)_{2}\left(\mu_{2}-\mathrm{SC}_{6} \mathrm{H}_{4}-\mathrm{R}^{2}\right)\right]^{+}$, bearing two types of thiol ligands. ${ }^{13-16,18,21-23,25,35-39}$ Like many organometallic compounds, these dinuclear thiolato-bridged arene ruthenium complexes have originally been designed as catalysts, for instance for the carbonylation of methanol. ${ }^{40}$ While they did not attract much attention for this application, a revival started in 2008, when water-soluble arene ruthenium complexes were discovered to be cytotoxic. ${ }^{14,40-44}$ Remarkably, almost all tested trithiolato compounds are highly cytotoxic with $\mathrm{IC}_{50}$ values being in the submicromolar range, the most potent ones with $\mathrm{IC}_{50}$ values of $30 \mathrm{nM}$ against A2780 cells and cisplatin-resistant A2780cisR cells. ${ }^{13,22,24,25}$ Recent in vivo studies have demonstrated that these complexes indeed have potential as anticancer drugs, since for instance the compound $\left[\left(\eta^{6}-\right.\right.$ $\left.\left.p-\mathrm{MeC}_{6} \mathrm{H}_{4} \mathrm{Pr}^{i}\right)_{2} \mathrm{Ru}_{2}\left(\mu_{2}-\mathrm{S}-p-\mathrm{C}_{6} \mathrm{H}_{4} \mathrm{Bu}^{t}\right)_{3}\right] \mathrm{Cl}$ (termed diruthenium1) significantly prolongs the survival of tumor-bearing mice ${ }^{17}$ and substantially influences metabolism of A2780cisR cells involving changes related to redox homeostasis, Warburg effect and lipid metabolism. ${ }^{45}$ Other derivatives appear less promising. ${ }^{44,46}$ Thiolato-bridged arene ruthenium complexes are also promising as antiprotozoal agents, with $\mathrm{IC}_{50}$ values of up to 1.2 nM against $T$. gondii and $N$. Caninum and $\mathrm{IC}_{50}$ values against human foreskin fibroblasts $>800 \mu \mathrm{M}$, leading to selectivity indexes $>200^{\prime} 000 .^{19,20}$ 


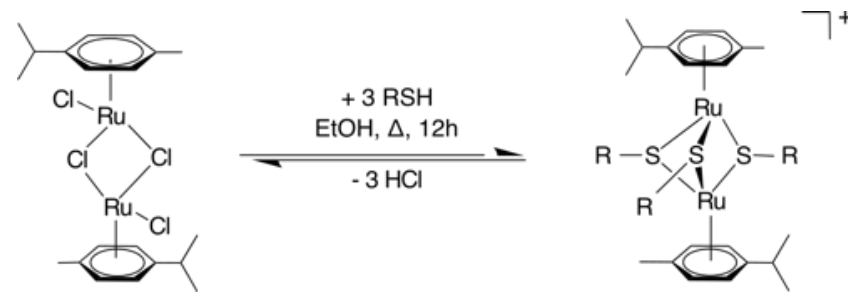

Scheme 1. Synthesis of dinuclear cationic trithiolato-bridged arene ruthenium complexes. ${ }^{36}$

The current synthesis route for obtaining dinuclear cationic trithiolato bridged arene ruthenium complexes of the general formula $\left[\left(\eta^{6}-p-\mathrm{MeC}_{6} \mathrm{H}_{4} \mathrm{Pr}^{i}\right)_{2} \mathrm{Ru}_{2}\left(\mu_{2}-\mathrm{S}-\mathrm{R}\right)_{3}\right]^{+}$with good yields dates back to the early 2000s and involves the reaction of the dimer $\left[\left(\eta^{6}-p-\mathrm{MeC}_{6} \mathrm{H}_{4} \mathrm{Pr}^{i}\right) \mathrm{Ru}\left(\mu_{2}-\mathrm{Cl}\right) \mathrm{Cl}\right]_{2}$ with an excess of the corresponding thiol (see Scheme 1) usually in refluxing ethanol $(\mathrm{EtOH}) .{ }^{36}$ For thiophenolato complexes, depending on the thiophenol used, it is possible to adjust the conditions to direct the synthesis exclusively to the cationic trithiophenolato complex $\left[\left(\eta^{6}-p-\mathrm{MeC}_{6} \mathrm{H}_{4} \mathrm{Pr}^{i}\right)_{2} \mathrm{Ru}_{2}\left(\mu_{2}-\mathrm{SC}_{6} \mathrm{H}_{4}-\mathrm{R}\right)_{3}\right]^{+},{ }^{18}$ the neutral dithiophenolato complex $\quad\left[\left(\eta^{6}-p-\mathrm{MeC}_{6} \mathrm{H}_{4} \mathrm{Pr}^{i}\right)_{2} \mathrm{Ru}_{2}\left(\mu_{2}-\mathrm{SC}_{6} \mathrm{H}_{4}-\right.\right.$ $\left.\mathrm{R})_{2} \mathrm{Cl}_{2}\right]{ }^{47}$ or even the neutral monothiophenolato complex $\left[\left(\eta^{6}-\right.\right.$ $\left.\left.p-\mathrm{MeC}_{6} \mathrm{H}_{4} \mathrm{Pr}^{i}\right)_{2} \mathrm{Ru}_{2} \mathrm{Cl}_{2}(\mu-\mathrm{Cl})\left(\mu_{2}-\mathrm{SC}_{6} \mathrm{H}_{4}-\mathrm{R}\right)\right]{ }^{48}$ The reactivity of the thiol undoubtedly plays an important role and decides to a great extent the outcome of the reaction. For instance, the trithiophenolato complexes $\left[\left(\eta^{6}-p-\mathrm{MeC}_{6} \mathrm{H}_{4} \mathrm{Pr}^{i}\right)_{2} \mathrm{Ru}_{2}\left(\mu_{2}-\mathrm{SC}_{6} \mathrm{H}_{4}-\mathrm{R}\right)_{3}\right]^{+}$ with the electron attracting substituents $\mathrm{R}=\mathrm{NO}_{2}$ or $\mathrm{R}=\mathrm{F}$ could so far be only obtained with moderate yields (48 and $45 \%$, respectively) using the standard strategy described in Scheme $1 .{ }^{22}$ Similarly, when much less reactive aliphatic thiols are used instead of aromatic ones, the reaction becomes more demanding and the desired trithiolato complexes are either obtained with modest yields or the reactions only give the neutral dithiolato complex. For instance, the trithiolato complex $\left[\left(\eta^{6}-p\right.\right.$ $\left.\left.\mathrm{MeC}_{6} \mathrm{H}_{4} \mathrm{Pr}^{i}\right)_{2} \mathrm{Ru}_{2}\left(\mu_{2}-\mathrm{SC}_{8} \mathrm{H}_{17}\right)_{3}\right]^{+}$was only obtained with a yield of $28 \%$, despite a long 7 day reaction in $\mathrm{EtOH}$ under inert atmosphere and reflux conditions, ${ }^{49}$ and the trithiolato complex $\left[\left(\eta^{6}-p-\mathrm{MeC}_{6} \mathrm{H}_{4} \mathrm{Pr}^{i}\right)_{2} \mathrm{Ru}_{2}\left(\mu_{2}-\mathrm{SC}_{6} \mathrm{H}_{11}\right)_{3}\right]^{+}$could not be obtained from the neutral dithiolato complex $\left[\left(\eta^{6}-p-\mathrm{MeC}_{6} \mathrm{H}_{4} \mathrm{Pr}^{i}\right)_{2} \mathrm{Ru}_{2}\left(\mu_{2^{-}}\right.\right.$ $\left.\mathrm{SC}_{6} \mathrm{H}_{11}\right)_{2} \mathrm{Cl}_{2}$ ], presumably due to steric reasons. ${ }^{47}$

These experimental facts raise the question as to whether the formation of dinuclear trithiolato-bridged arene ruthenium complexes with different thiols is thermodynamically or kinetically hindered, which would give indications as to how conditions should be altered to enable reactions or to improve yields. Additionally, knowing more about the mechanism of formation could be helpful when elucidating the fate of the complex once it enters the cell and to understand what leads to its toxicity.

In the present work we aim at a fundamental understanding of the reaction mechanisms leading to the formation of trithiolato complexes starting from the dichloro( $p$-cymene)ruthenium(II) dimer $\left[\left(\eta^{6}-p-\mathrm{MeC}_{6} \mathrm{H}_{4} \mathrm{Pr}^{i}\right) \mathrm{Ru}\left(\mu_{2}-\mathrm{Cl}\right) \mathrm{Cl}\right]_{2}$ and to modify, where necessary, the existing synthetic route to (i) increase the yields, (ii) reduce the overall reaction time (currently reflux in EtOH, 18h), and to (iii) synthesize novel trithiolato complexes. To this end, we employ density functional theory (DFT) calculations of the possible synthetic routes for trithiolato complexes $\left[\left(\eta^{6}-p\right.\right.$ $\left.\left.\mathrm{MeC}_{6} \mathrm{H}_{4} \mathrm{Pr}^{i}\right)_{2} \mathrm{Ru}_{2}\left(\mu_{2}-\mathrm{SR}\right)_{3}\right]^{+}$. The results of the DFT agree with new experimental results obtained for the trithiophenolato complexes $\left[\left(\eta^{6}-p-\mathrm{MeC}_{6} \mathrm{H}_{4} \mathrm{Pr}^{i}\right)_{2} \mathrm{Ru}_{2}\left(\mu_{2}-\mathrm{SC}_{6} \mathrm{H}_{4}-\mathrm{R}\right)_{3}\right]^{+}$with $\mathrm{R}=\mathrm{H}$ (1), $\mathrm{R}=p$-OMe (2), and $\mathrm{R}=p-\mathrm{NO}_{2}(3)$, and the previously unreported trithiolato complex $\left[\left(\eta^{6}-p-\mathrm{MeC}_{6} \mathrm{H}_{4} \mathrm{Pr}^{i}\right)_{2} \mathrm{Ru}_{2}\left(\mu_{2}-\right.\right.$ $\left.\left.\mathrm{SC}_{6} \mathrm{H}_{11}\right)_{3}\right]^{+}(4)$ by using a modified synthetic routes (see Figure 1).
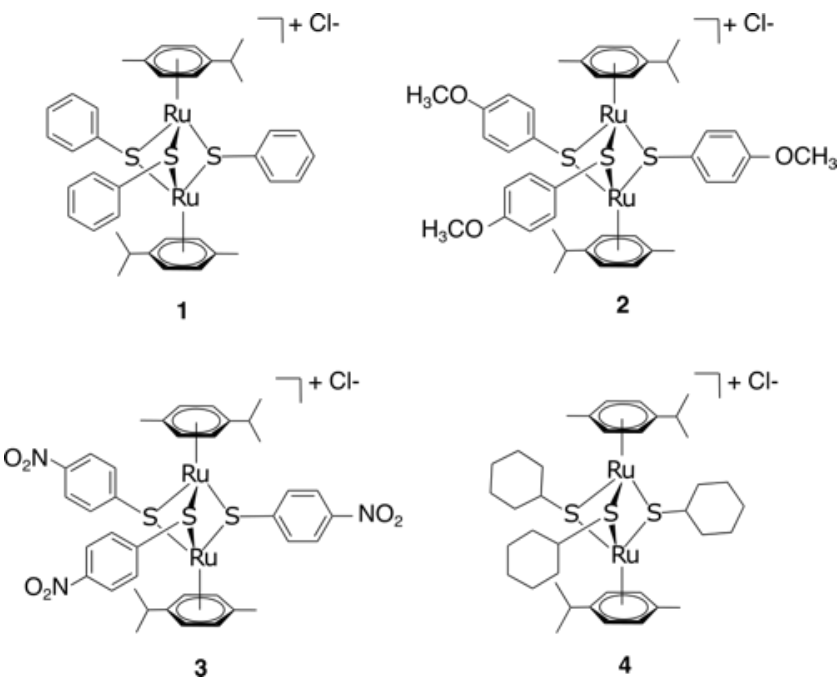

Figure 1. Structure of the four dinuclear trithiolato-bridged arene ruthenium complexes.

\section{RESULTS AND DISCUSSION}

1) DFT calculations

Formation mechanism. The formation of dinuclear trithiolatobridged arene ruthenium complexes is assumed to follow a three-step substitution mechanism (see Figure 2). In each of the first two steps, one of the bridging chlorine atoms is substituted by a thiolate ligand. The last step consists in accommodating the third bridging thiol, while releasing at the same time the remaining non-bridging chlorine atoms. Each of these steps is accompanied by the formation of one equivalent $\mathrm{HCl}$ while, additionally, in the last step, the complex acquires a singly positive charge with one chlorine ion providing counter charge. Each of the three individual steps consists of the release of the chlorine, the deprotonation of the thiol group and the insertion of the sulfur atom, the exact sequence of these sub steps as well as their respective contribution to the overall reaction barrier being unknown. Such detailed information on the formation mechanism would however be crucially required for a knowledge-based optimization of the synthesis conditions and the yield of such complexes. We hence determine the mechanism of each individual step by means of density functional theory (DFT) calculations. 

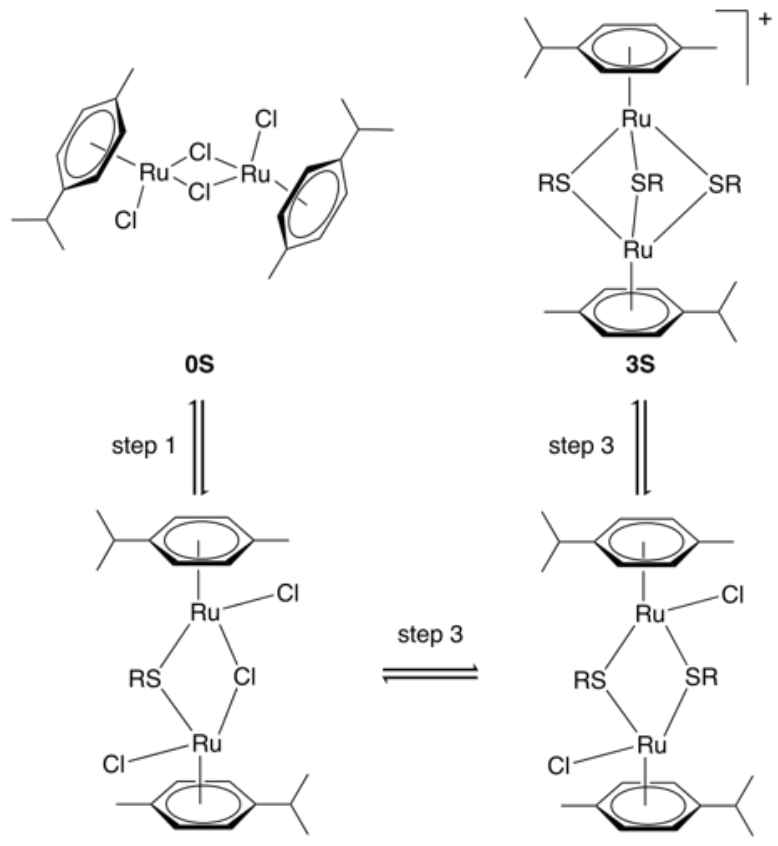

$1 \mathrm{~S}$

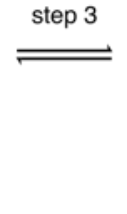

Figure 2. Stepwise formation of dinuclear trithiolato-bridged arene ruthenium complexes. We adopted the following abbreviations for the complexes - starting dimer $\left[\left(\eta^{6}-p-\mathrm{MeC}_{6} \mathrm{H}_{4} \mathrm{Pr}^{i}\right) \mathrm{Ru}\left(\mu_{2}-\mathrm{Cl}\right) \mathrm{Cl}\right]_{2}$ : OS, neutral monothiolato complex $\left[\left(\eta^{6}-p-\mathrm{MeC}_{6} \mathrm{H}_{4} \mathrm{Pr}^{i}\right)_{2} \mathrm{Ru}_{2} \mathrm{Cl}_{2}(\mu-\right.$ $\left.\mathrm{Cl})\left(\mu_{2}-\mathrm{SR}\right)\right]$ : 1S, neutral dithiolato complex $\left[\left(\eta^{6}-p-\right.\right.$ $\left.\left.\mathrm{MeC}_{6} \mathrm{H}_{4} \mathrm{Pr}^{i}\right)_{2} \mathrm{Ru}_{2}\left(\mu_{2}-\mathrm{SR}\right)_{2} \mathrm{Cl}_{2}\right]: \mathbf{2 S}$ and cationic trithiolato complex $\left[\left(\eta^{6}-p-\mathrm{MeC}_{6} \mathrm{H}_{4} \mathrm{Pr}^{i}\right)_{2} \mathrm{Ru}_{2}\left(\mu_{2}-\mathrm{SR}\right)_{3}\right]^{+}: \mathbf{3 S}$.

We tested two pathways for the insertion of the first thiol. The first pathway proceeds by initially forming a $\mathrm{Ru}-\mathrm{S}$ bond with the subsequent release of $\mathrm{HCl}$ and the second one by reversing these steps with initial $\mathrm{HCl}$ formation followed by insertion of the thiolate. We find both pathway initializations to converge to the same final mechanism with two transition states (see Figure S1a). The first lower-energy transition state corresponds to the $\mathrm{Ru}-\mathrm{S}$ bond formation $(12.8 \mathrm{kcal} / \mathrm{mol})$, whereas the second higher-energy transition state is the thiol deprotonation (19.9 kcal/mol). In protic solvents thiols could exist as deprotonated anions and we would expect a reduced barrier for the second step. This is indeed confirmed by our calculations, where the barrier of insertion of the thiolate is reduced by $8.8 \mathrm{kcal} / \mathrm{mol}$ (see Figure S2). As these deprotonated systems are not charge neutral and computationally more challenging in our periodic setup, we will in the following consider only reaction mechanism for the neutral molecule but assume that protic solvents should systematically reduce reaction barriers.

The insertion of the second thiophenol follows the same mechanism as for the first one. However, the accommodation of the thiol in the Ru-complex core is hindered, which is reflected in the first transition state having a much higher activation barrier (24.0 kcal/mol, see Figure S1b). The deprotonation step on the other hand requires less energy $(10.9 \mathrm{kcal} / \mathrm{mol})$ than for the first insertion. The final step in the formation of the trithiolato $\mathrm{Ru}$ complex is kinetically most demanding. While the barrier for the $\mathrm{Ru}-\mathrm{S}$ bond formation is similar to the two preceding steps $(17.5 \mathrm{kcal} / \mathrm{mol})$, the deprotonation is accompanied by rearrangement of the two other thiol ligands, so as to accommodate the third one, which results in a barrier of $31.4 \mathrm{kcal} / \mathrm{mol}$ (see Figure S1c). The overall pathway for thiol ligands is shown as the black curve in Figure 3. It can be seen that the formation of all thiolato complexes is thermodynamically favorable. Nevertheless, the kinetic barriers continuously increase from formation of the monothiolato to the formation of the trithiolato complex, in correlation with lower experimental yield for the trithiolato complexes compared to mono- and dithiolato ones.

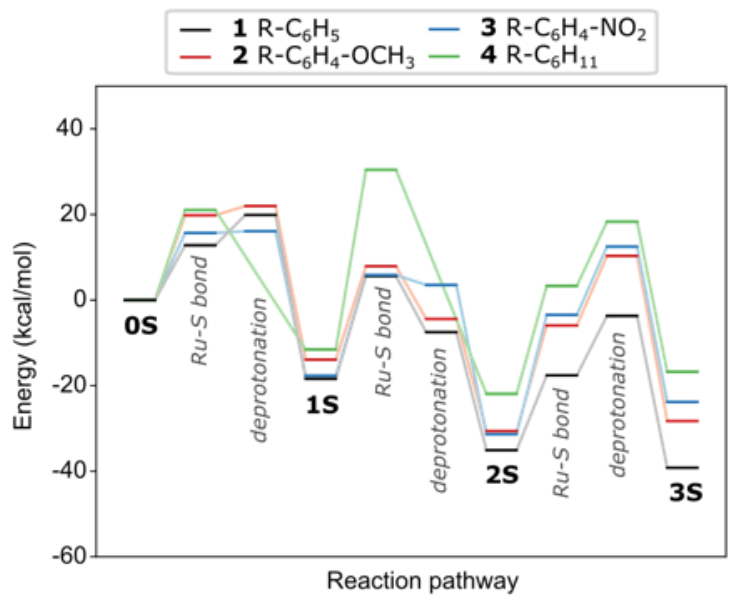

Figure 3. Energy evolution and transition states along the formation pathway form the starting dimer dichloride $(\mathbf{0 S})$ to the trithiolato (3S) Ru complex via the mono- (1S) and dithiolato complexes. The black line represents thiophenol, while the red, blue and green lines are for thiophenols with $-\mathrm{OCH}_{3}$ and $-\mathrm{NO}_{2}$ substituents in para position and cyclohexanethiol respectively. The values for the kinetic barriers are summarized in Table S1 (SI).

Electron withdrawing/donating substituents. The reactivity of arene ligands can be tuned by the presence of different substituents on the benzene ring. For thiophenol, the presence of a strong electron withdrawing $-\mathrm{NO}_{2}$ group is expected to facilitate deprotonation. Indeed, we compute a deprotonation barrier that is $2.9 \mathrm{kcal} / \mathrm{mol}$ lower with the $-\mathrm{NO}_{2}$ group in p-position than without it (see Figure 3 and Figure S4). This kinetic enhancement is however not observed for the formation of the di- and trithiolato complex, where we predict almost no change in barrier and an increase by $10.4 \mathrm{kcal} / \mathrm{mol}$, respectively. In addition, the formation of the trithiolato complex is thermodynamically no longer favorable in presence of the $-\mathrm{NO}_{2}$ group. The opposite effect in terms of deprotonation is expected for electron donating substituents, such as a methoxy group and indeed we systematically predict a slight increase in the deprotonation activation energies with respect to the non-substituted ligands. Also, for the $-\mathrm{OCH}_{3}$ substituent the formation of the trithiolato complex is kinetically strongly hindered and thermodynamically no longer favorable. In both cases the destabilization of the trithiolato complex can be ascribed on one hand to the increased steric bulkiness of the ligands, which negatively affects the overall cluster geometry. Indeed, while the $\mathrm{Ru}-\mathrm{Ru}$ distance remains unaltered, the average S-S distance in the $\mathbf{3 S}$ core of $\mathbf{2}$ and $\mathbf{3}$ increases from $3.042 \AA$ for 1 to $3.056 \AA$ and $3.061 \AA$, respectively, indicating for a slight strain the complex core. On the other hand, the destabilization can be attributed to the significant dipole moment each thiolato-ligand carries and introduces into the complex. In fact, both $-\mathrm{OCH}_{3}$ and $-\mathrm{NO}_{2}$ have non-negligible Hammett substituent constants $\sigma_{\mathrm{p}}, \quad-0.27$ and $0.78^{50}$ 
respectively, which reflect the strong electron asymmetry within such thiols. The fact that $\mathbf{3 S}$ is destabilized disagrees with the experimental data, since the trithiolato $-\mathrm{NO}_{2}$ complex can be obtained in good yields (when performing the reaction in DCM, see Experimental Section). We ascribe this to the lack of any stabilization effects coming from the solvent in the calculations as opposed to the experiment.

Aliphatic thiol. We investigated the formation of the trithiolato complex in the case of the bulky aliphatic cyclohexanethiol. The insertion of the ligand and the formation of the Ru-S bond is the only transition state for the first two steps (see Figure 3 and Figure S5). The energy necessary to insert the first cyclohexanethiol is similar to the other ligands, whereas the barrier of the second step is significantly higher, which could kinetically hinder the formation of the di- and trithiolato complexes. The final step, however, also has a transition state corresponding to the deprotonation step, in agreement with all other trithiolato-complexes. The kinetic barriers of this $\mathbf{2 S} \rightarrow \mathbf{3 S}$ step are still comparable to those for the substituted aromatic thiols.

Effect of the halogen in the starting dimer $\left[\left(\eta^{6}-p\right.\right.$ $\left.\left.\mathbf{M e C}_{6} \mathbf{H}_{4} \mathbf{P r}^{i}\right) \mathbf{R u}\left(\boldsymbol{\mu}_{2}-\mathbf{C l}\right) \mathbf{C l}\right]_{2}$. Next, we investigate what effect the halogen has on the reaction by substituting chlorine with iodine in the starting dimer $\left[\left(\eta^{6}-p-\mathrm{MeC}_{6} \mathrm{H}_{4} \mathrm{Pr}^{i}\right) \mathrm{Ru}\left(\mu_{2}-\mathrm{I}\right) \mathrm{I}\right]_{2}$. In Figure 4 we compare the energy evolution of the three reaction steps and see that iodine increases (by $9.9 \mathrm{kcal} / \mathrm{mol}$ ) the barrier of the first step, changing it to the Ru-S bond formation instead of the deprotonation. The barriers for the subsequent steps remain roughly the same as for chlorine (see Table S2 for numerical values). We observe however a reduced thermodynamic stability in presence of iodine, the mono-, di- and trithiolato complexes being significantly less stable than their chlorine counterparts and the formation of the trithiolato complex even being uphill in energy. As the structure of the trithiolato complex itself is the same for both halogens, this can be attributed to the weaker $\mathrm{H}-\mathrm{I}$ bond compared to $\mathrm{H}-\mathrm{Cl}$. While the kinetics are thus only mildly affected by iodine, we expect significantly less driving force for the formation of the thiolato complexes. Experimental results have indeed shown that trithiolato complexes $\left[\left(\eta^{6}-p-\mathrm{MeC}_{6} \mathrm{H}_{4} \mathrm{Pr}^{i}\right)_{2} \mathrm{Ru}_{2}\left(\mu_{2}-\mathrm{SC}_{6} \mathrm{H}_{4}-\mathrm{R}\right)_{3}\right]^{+}$starting from $\left[\left(\eta^{6}-p-\mathrm{MeC}_{6} \mathrm{H}_{4} \mathrm{Pr}^{i}\right) \mathrm{Ru}\left(\mu_{2}-\mathrm{I}\right) \mathrm{I}\right]_{2}$ could not be obtained in pure form. ${ }^{51}$

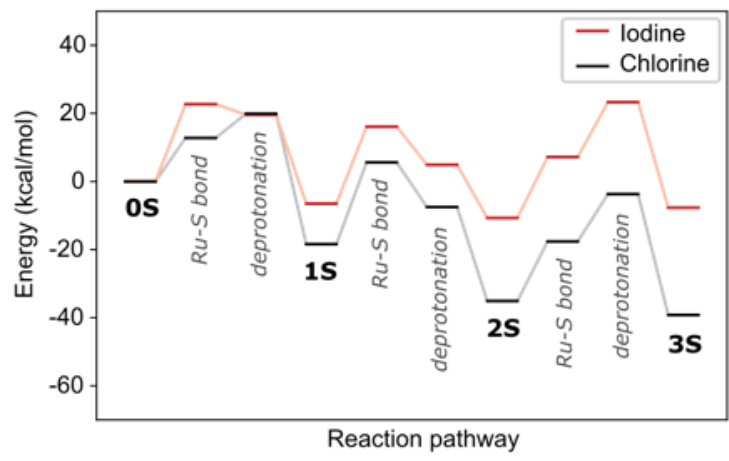

Figure 4. Energy evolution of the thiolate complex 1 formation in presence of chlorine and iodine. The transition-state barriers are presented numerically in Table S2 (SI) and the NEB pathways can be found in Figure S6 (SI).
Temperature and solvent effects. Based on the computed barriers, we estimate the reaction rates at $0^{\circ} \mathrm{C}, 25^{\circ} \mathrm{C}, 45^{\circ} \mathrm{C}$ and $80^{\circ} \mathrm{C}$, where the last two temperatures correspond to the usual experimental conditions in dichlormethane (DCM) and ethanol respectively (see Section 2, Experimental results), using Eyring's equation ${ }^{52}$ within transition state theory the reaction rate is

$$
k=\frac{k_{B} T}{h} e^{-\frac{E^{\#}}{k_{B} T}}
$$

where $k_{B}$ is Boltzmann's constant, $T$ the temperature, $h$ Plank's constant, and $E^{\#}$ is the computed barrier, listed in Table S1. From the data shown in Figure 5 and Table S4, we can see that while steps 1 and 2 have reasonable reaction rates at room temperature, step 3 has very slow kinetics, which is further hindered by the substituents on the thiophenol. Only elevated temperatures lead to reaction rates that enable the complex formation on experimental timescales. These are in agreement with the experimental findings, that the $3^{\text {rd }}$ step needs significant thermal energy to proceed.

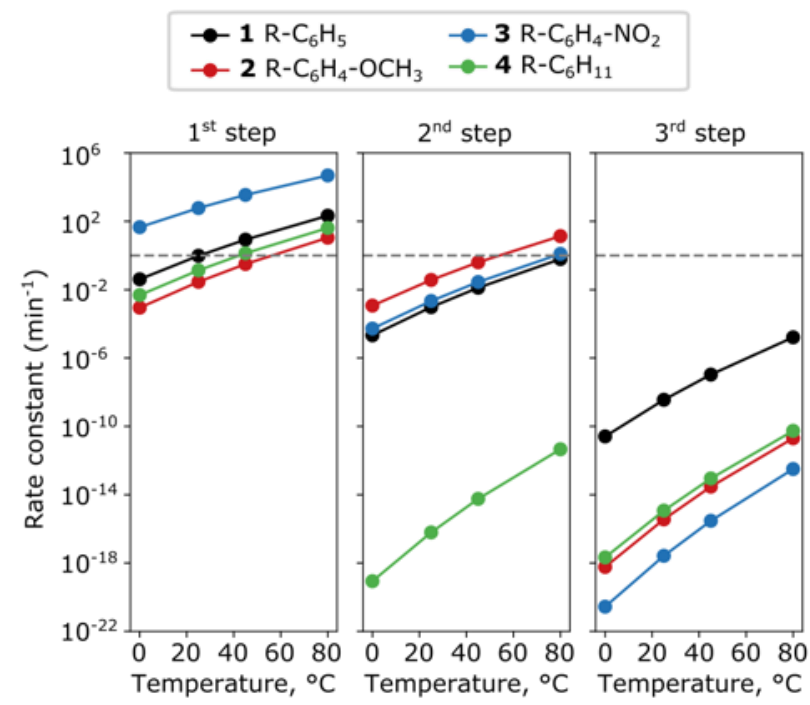

Figure 5. Change in the rate constants with temperature for the Complexes 1-4 for the three steps. The numerical values are summarized in Table S4 (SI).

Experimentally, the three-step reaction takes place in a polar solvent, ethanol or DCM (in the present work). We simulate the presence of the solvent with an implicit solvation model, which correctly describes the electrostatic effect of medium, but does not account for any reaction with the solvent such as H-bonding or proton transfer. The energy evolution in the two solvents is shown in Figure 6 and compared with the one in vacuum. DCM has a distinct destabilizing effect on the transition states corresponding to the insertion of the thiol group into the complex' core. Conversely, it appears to slightly stabilize the trithiolato complex, making its formation more likely, which is in agreement with the experimental observations. The effect of the protic polar solvent ethanol can be seen as a systematic stabilization of the complexes, a kinetically faster formation of the monothiolato complex but also a dramatic increase of the barriers corresponding to the insertion of the thiol groups during the formation of the di- and trithiolato complexes. This last effect may 
not be entirely meaningful, however, as our implicit solvent model lacks the ability to stabilize transition states by $\mathrm{H}$-bond formation.

The effect of the temperature on the reaction kinetics and the individual insertion of the thiol has already been experimentally demonstrated. For a given thiol, it was shown that the synthesis exclusively leads to the cationic trithiophenolato complex $\left[\left(\eta^{6}-\right.\right.$ $\left.\left.p-\mathrm{MeC}_{6} \mathrm{H}_{4} \mathrm{Pr}^{i}\right)_{2} \mathrm{Ru}_{2}\left(\mu_{2}-\mathrm{SC}_{6} \mathrm{H}_{4}-\mathrm{R}\right)_{3}\right]^{+}$. At $0^{\circ} \mathrm{C}$ and for thiols with decreased reactivity, typically benzylthiols, but also for some thiophenols, the neutral dithiophenolato complex $\left[\left(\eta^{6}-p\right.\right.$ $\left.\left.\mathrm{MeC}_{6} \mathrm{H}_{4} \mathrm{Pr}^{i}\right)_{2} \mathrm{Ru}_{2}\left(\mu_{2}-\mathrm{SC}_{6} \mathrm{H}_{4}-\mathrm{R}\right)_{2} \mathrm{Cl}_{2}\right]$,[45] or even the neutral monothiophenolato complex $\left[\left(\eta^{6}-p-\mathrm{MeC}_{6} \mathrm{H}_{4} \mathrm{Pr}^{i}\right)_{2} \mathrm{Ru}_{2} \mathrm{Cl}_{2}(\mu-\right.$ $\left.\mathrm{Cl})\left(\mu_{2}-\mathrm{SC}_{6} \mathrm{H}_{4}-\mathrm{R}\right)\right]$ can be obtained in pure forms. ${ }^{48}$

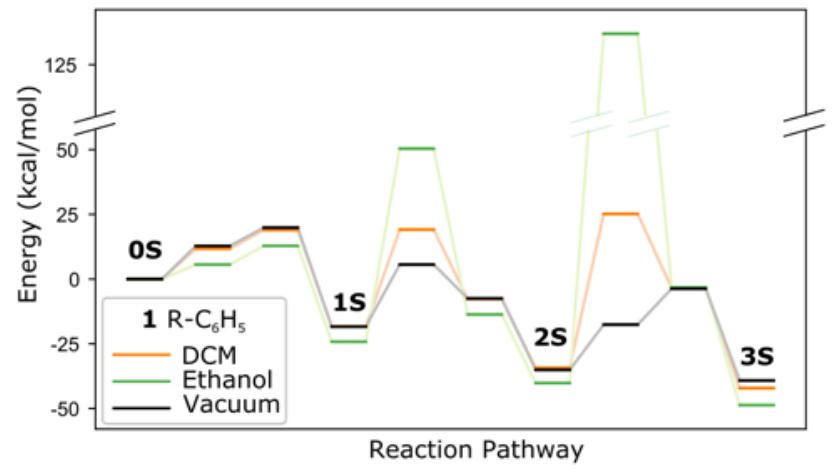

Figure 6. Effect of implicit DCM and ethanol solvents on the energy evolution. The numerical values are in Table S3 (SI).

\section{2) Experimental results}

Synthesis of complexes 1-3. The reaction pathway shown in Figure 6 suggests changing the solvent from the usual EtOH to DCM, as the former leads to an increase of the kinetic barriers for the formation of the di- and especially trithiolato complexes. Trithiolato complexes should therefore be easier to access from the reaction performed in DCM.

Recently undertaken experimental assays confirm the theoretical prediction: in DCM, the complex $\left[\left(\eta^{6}-p\right.\right.$ $\left.\left.\mathrm{MeC}_{6} \mathrm{H}_{4} \mathrm{Pr}^{i}\right)_{2} \mathrm{Ru}_{2}\left(\mu_{2}-\mathrm{SC}_{6} \mathrm{H}_{4}-p-\mathrm{Bu}^{t}\right)_{3}\right]^{+}$, diruthenium-1, closely related to $\mathbf{1}$, could be obtained quantitatively in $2 \mathrm{~h}$ when the reaction is conducted in DCM under reflux at $40^{\circ} \mathrm{C}$, as compared to $85 \%$ yield when the reaction is conducted in EtOH under reflux at $80^{\circ} \mathrm{C} .^{53}$

Complex 1 was obtained with a yield of $62 \%$ after a $7 \mathrm{~h}$ reaction performed at $45^{\circ} \mathrm{C}$ in DCM as compared to a $69 \%$ yield obtained from the same reaction but performed in $\mathrm{EtOH}$ at $80^{\circ} \mathrm{C}$ for $23 \mathrm{~h}$. In literature, $44 \%$ yield was reached for the reaction performed in $\mathrm{MeOH} .{ }^{34}$ More interestingly, irrespective of the solvent used, EtOH or DCM, the addition of N,N-Diisopropylethylamine (DIPEA) $1 \mathrm{~h}$ after beginning of the reaction allowed obtaining 1 in $80 \%$ or $79 \%$ yield, respectively, in only $3 \mathrm{~h}$. The reaction leading to complex 1 was followed by NMR spectroscopy (Figure 7-8; S9-10). It can be seen that at elevated temperatures, the dithiolato complex is readily formed followed by formation of the trithiolato complex. Interestingly, it seems that in DCM at $45^{\circ} \mathrm{C}$ the trithiolato complex is formed slightly faster compared to the reaction performed in $\mathrm{EtOH}$ at $80^{\circ} \mathrm{C}$. The reaction was also performed in $\mathrm{CD}_{2} \mathrm{Cl}_{2}$ at $25^{\circ} \mathrm{C}$ and $0^{\circ} \mathrm{C}$ respectively, and followed by ${ }^{1} \mathrm{H} \mathrm{NMR}$, in order to determine experimental rate constants $k$ using Dynamics Center 2.5 .6 software. ${ }^{54-56}$ From the reactions performed at $0^{\circ} \mathrm{C}$ and $25^{\circ} \mathrm{C}$, we were only able to derive the rate constant for the dithiolato complex, which comprises both the first and second substitution step applying the Bodenstein approximation. The monothiolato formation happens very fast and no reliable NMR data could be extracted. It turns out that the rate constant obtained from the kinetic data (see Table 1 and Figure S11-12) was of the same order of magnitude as the one calculated in case of the reaction performed at $25^{\circ} \mathrm{C}$. Surprisingly and unlike theoretically predicted, the rate constant $k$ at $0^{\circ} \mathrm{C}$ is of similar order of magnitude.

Complex 2 was obtained in $73 \%$ yield from the reaction performed at $45^{\circ} \mathrm{C}$ in DCM after $9 \mathrm{~h}$ as compared to $93 \%$ yield obtained from $18 \mathrm{~h}$ reaction performed in $\mathrm{EtOH}$ at $80^{\circ} \mathrm{C}^{57}$. The rate constant $k$ of the corresponding dithiolato complex obtained from the reaction in $\mathrm{CD}_{2} \mathrm{Cl}_{2}$ followed by ${ }^{1} \mathrm{H} \mathrm{NMR}$ was close to the calculated $k$ (see Table 1 and Figure 9, S13-14). Surprisingly and in contrast to calculations, $\mathrm{k}$ obtained for the reaction performed at $25^{\circ} \mathrm{C}$ was lower than at $0^{\circ} \mathrm{C}$. This could be ascribed to the different dependence of the forward and backward reaction rates with temperature (see Tables S4 and S5), if we assume the process to be in equilibrium. Indeed, the equilibrium constant $K$ at $0^{\circ} \mathrm{C}$ is higher than the one at $25^{\circ} \mathrm{C}$ (see Table S6), so the forward reaction is favored at lower temperatures. Interestingly, such a rate dependence is not observed for $\mathbf{1}$, even though, based on the calculations, we would expect even higher differences in $K$. This leads us to conclude that further processes and factors not captured by the calculations, i.e. solvents and entropy, ${ }^{58}$ are likely to play a role.

Complex 3 A yield of $73 \%$ of $\mathbf{3}$ was reached when the reaction was performed in DCM at $45^{\circ} \mathrm{C}$ compared to $48 \%$ reported in literature for the reaction performed in $\mathrm{EtOH}$ at $80^{\circ} \mathrm{C}$ for $18 \mathrm{~h}$. In case of 3 , the reaction in $\mathrm{CD}_{2} \mathrm{Cl}_{2}$ was followed at $0^{\circ} \mathrm{C}$ and $25^{\circ} \mathrm{C}$ as well. The rate constant obtained for corresponding dithiolato complex was of the same order of magnitude as the one calculated in case of the reaction performed at $0^{\circ} \mathrm{C}$ (Table 1; Figure S15-16). Similarly to 2 , the reaction appears to be faster at $0^{\circ} \mathrm{C}$ as opposed to $25^{\circ} \mathrm{C}$. At $45^{\circ} \mathrm{C}$, the starting material seems to be reacting almost immediately with the thiol (Figure S1516).

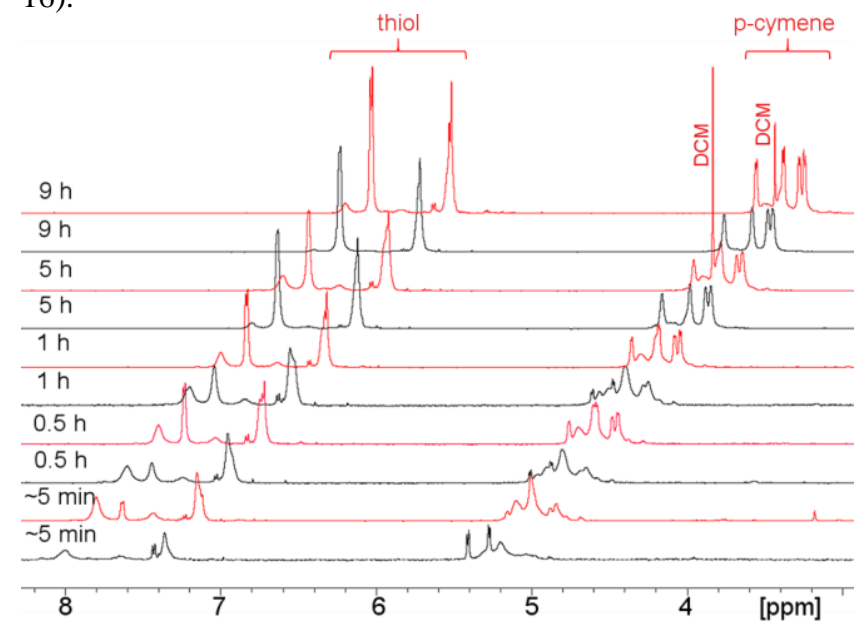

Figure 7. Synthesis of $\mathbf{1}$ in EtOH (black line) at $80^{\circ} \mathrm{C}$ and $\mathrm{DCM}$ (red line) at $45^{\circ} \mathrm{C}$ followed by ${ }^{1} \mathrm{H}$ NMR in time (a) $\sim 5 \mathrm{~min}$, (b) $0.5 \mathrm{~h}$, (c) $1 \mathrm{~h}$, (d) $5 \mathrm{~h}$, (e) $9 \mathrm{~h}$. Thiol and p-cymene aromatic 
resonances. Aliquots of reaction mixture samples at individual time points were dried and transferred to $\mathrm{CDCl}_{3}$ prior to measurement.

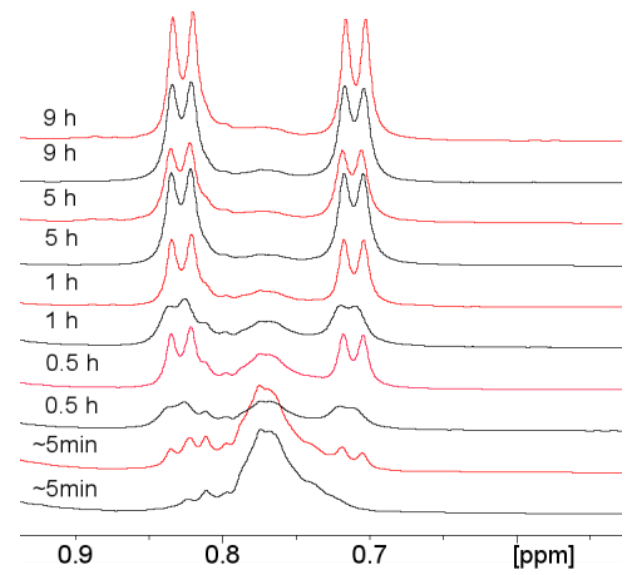

Figure 8. Kinetics of the synthesis of $\mathbf{1}$ in $\mathrm{EtOH}$ (black line) at $80^{\circ} \mathrm{C}$ and DCM (red line) at $45^{\circ} \mathrm{C}$ followed by ${ }^{1} \mathrm{H} \mathrm{NMR}$ in time (a) $~ 5 \mathrm{~min}$, (b) $0.5 \mathrm{~h}$, (c) $1 \mathrm{~h}$, (d) $5 \mathrm{~h}$, (e) $9 \mathrm{~h}$. The spectra show the resonance of the two methyl groups of the isopropyl group in the $p$-cymene ring. Aliquots of reaction mixture samples at individual time points were dried and transferred to $\mathrm{CDCl}_{3}$ prior to measurement.

Table 1. Rate constants $k$ for the first two steps calculated from the constants of the individual steps (see Table S4) or determined experimentally from NMR kinetic data, respectively.

\begin{tabular}{|l|l|l|l|l|}
\hline \multirow{2}{*}{$\mathrm{R}$} & \multicolumn{3}{|l|}{$\mathrm{k}_{\text {steps } 1+2}\left(\mathrm{~min}^{-1}\right)$} \\
\cline { 2 - 5 } & \multicolumn{3}{|l|}{ Calculated } & \multicolumn{2}{l|}{ Experimental } \\
\cline { 2 - 5 } & $0^{\circ} \mathrm{C}$ & $25^{\circ} \mathrm{C}$ & $0^{\circ} \mathrm{C}$ & $25^{\circ} \mathrm{C}$ \\
\hline$-\mathrm{C}_{6} \mathrm{H}_{5}(\mathbf{1})$ & $8.6 \cdot 10^{-7}$ & $9.2 \cdot 10^{-2}$ & $7.5 \cdot 10^{-4}$ & $2.9 \cdot 10^{-3}$ \\
\hline$-\mathrm{C}_{6} \mathrm{H}_{4} \mathrm{OMe}(\mathbf{2})$ & $1.1 \cdot 10^{-6}$ & $1.1 \cdot 10^{-3}$ & $6.5 \cdot 10^{-3}$ & $2.2 \cdot 10^{-3}$ \\
\hline$-\mathrm{C}_{6} \mathrm{H}_{4} \mathrm{NO}_{2}(\mathbf{3})$ & $2.4 \cdot 10^{-3}$ & 1.32 & $9.2 \cdot 10^{-3}$ & $1.2 \cdot 10^{-3}$ \\
\hline
\end{tabular}

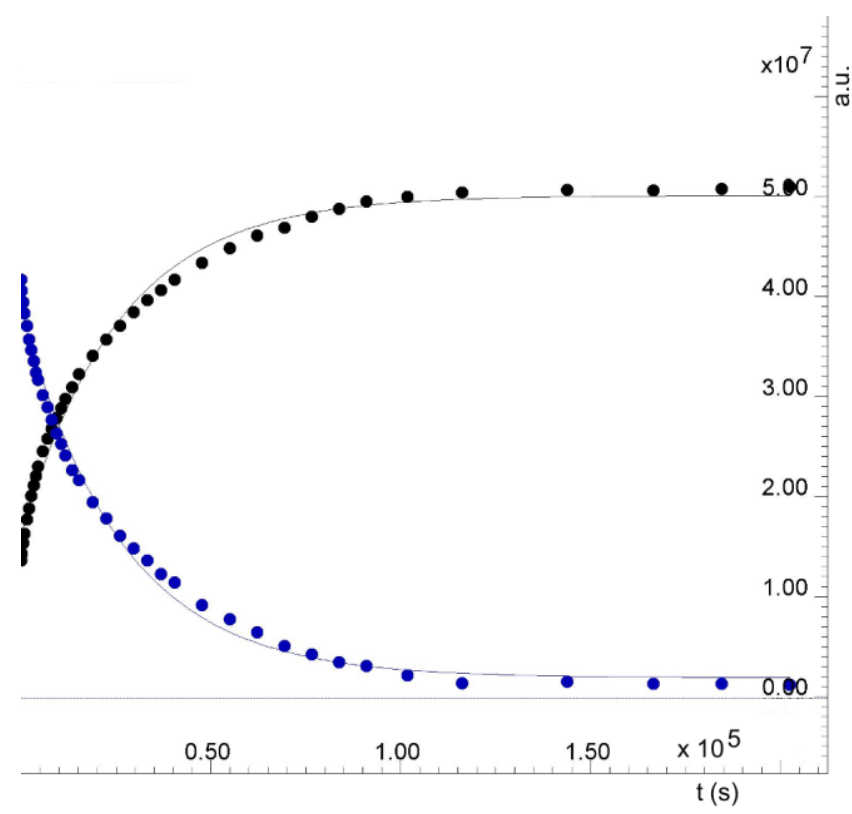

Figure 9. Reaction between the dimer $\left[\left(\eta_{6}-\mathrm{p}-\right.\right.$ $\left.\left.\mathrm{MeC}_{6} \mathrm{H}_{4} \mathrm{Pr}^{i}\right) \mathrm{Ru}\left(\mu_{2}-\mathrm{Cl}\right) \mathrm{Cl}\right]_{2}$ and $p$-methoxythiophenol in $\mathrm{CD}_{2} \mathrm{Cl}_{2}$ at $25^{\circ} \mathrm{C}$. In black signal at $6.86 \mathrm{ppm}$, in blue signal at $5.34 \mathrm{ppm}$ followed by ${ }^{1} \mathrm{H} \mathrm{NMR}$.

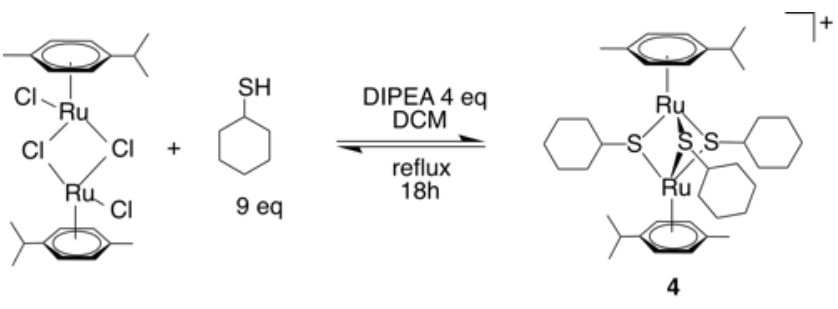

Scheme 2. Modified synthetic route for obtaining the new complex 4.

Synthesis of the new complex 4 . The synthesis of complex 4 was attempted several years ago by Süss-Fink and coworkers, but they could only obtain the neutral dithiolato complex $\left[\left(\eta^{6}-\right.\right.$ $\left.p-\mathrm{MeC}_{6} \mathrm{H}_{4} \mathrm{Pr}^{i}\right)_{2} \mathrm{Ru}_{2}\left(\mu_{2}-\mathrm{SC}_{6} \mathrm{H}_{11}\right)_{2} \mathrm{Cl}_{2}$, which did not react further in ethanol heated at reflux, presumably due to steric reasons. ${ }^{47}$ The difficulty to obtain the trithiolato complex $\mathbf{4}$ is in line with the computational results discussed above. Nevertheless, by significantly extending the reaction time (5-24 days), performing the reaction in DCM and using activating DIPEA, we were able to obtain complex $\mathbf{4}$, however not in a pure form, as mixtures containing the dithiolato complex $\left[\left(\eta^{6}-p\right.\right.$ $\left.\mathrm{MeC}_{6} \mathrm{H}_{4} \mathrm{Pr}^{i}\right)_{2} \mathrm{Ru}_{2}\left(\mu_{2}-\mathrm{SC}_{6} \mathrm{H}_{11}\right)_{2} \mathrm{Cl}_{2}$ ] (and possibly other impurities) were always obtained. The attempt to follow kinetics of cyclohexylthiol with $\mathrm{Ru}$ dimer in $\mathrm{CD}_{2} \mathrm{Cl}_{2}$ followed by ${ }^{1} \mathrm{H}$ NMR in order to obtain $k$ was not successful in this case. Only a slight hint on slow kinetics of the reaction could be obtained (Figure S19-20).

\section{CONCLUSION}

In summary, we have conducted a DFT study aiming at a fundamental understanding of the reaction mechanisms leading to 
the formation of dinuclear trithiolato-bridged arene ruthenium complexes $\left[\left(\eta^{6}-p-\mathrm{MeC}_{6} \mathrm{H}_{4} \mathrm{Pr}^{i}\right)_{2} \mathrm{Ru}_{2}\left(\mu_{2}-\mathrm{SC}_{6} \mathrm{H}_{4}-\mathrm{R}\right)_{3}\right]^{+} \quad$ starting from the dichloro(p-cymene)ruthenium(II) dimer $\left[\left(\eta^{6}-p\right.\right.$ $\left.\left.\mathrm{MeC}_{6} \mathrm{H}_{4} \mathrm{Pr}^{i}\right) \mathrm{Ru}\left(\mu_{2}-\mathrm{Cl}\right) \mathrm{Cl}\right]_{2}$. Further, we studied variations in reaction conditions experimentally and followed its kinetics with NMR.

The presence of electron-withdrawing or-donating substituents on the thiol significantly influences the formation of the trithiolato complex, which is thermodynamically no longer favorable in presence of electron-withdrawing substituents. Importantly, the reaction pathway suggests changing the solvent from the usual EtOH to DCM, as the former leads to a dramatic increase of the kinetic barriers for the formation of the di- and trithiolato complexes.

Experimentally, changing the reaction solvent to DCM leads mostly to similar or better yields at lower temperature as compared to EtOH. Use of base such as DIPEA allows further increase of the yield in shorter reaction time. Additionally, formerly unobtainable $\left[\left(\eta^{6}-p-\mathrm{MeC}_{6} \mathrm{H}_{4} \mathrm{Pr}^{\mathrm{i}}\right)_{2} \mathrm{Ru}_{2}\left(\mu_{2}-\mathrm{SC}_{6} \mathrm{H}_{11}\right)_{3}\right]^{+}$was formed following slow reaction kinetics.

As such, our DFT study and suggested modified synthetic route opens new possibilities and the synthesis of so far inaccessible dinuclear thiophenolato- and especially thiolato-bridged arene ruthenium(II) complexes but more generally also of other challenging or considered hitherto as unobtainable thiolato-bridged dinuclear group 8 and 9 metal complexes shall be reexamined.

\section{COMPUTATIONAL SECTION}

All calculations were carried out with the $\mathrm{CP} 2 \mathrm{~K}$ package ${ }^{59}$ within the mixed Gaussian and Plane-Wave DFT formalism. ${ }^{60,61}$ The core-region of wave functions was smoothed out with norm-conserving dual-space Goedecker-Teter-Hutter pseudopotentials ${ }^{62,63}$, whereas the valence pseudo-wave functions were expanded in molecularly optimized double-zeta valence polarized (DZVP) Gaussian basis sets for all elements. ${ }^{64}$ The auxiliary plane-wave basis set, used to calculate the Hartree potential, had a cut-off of $750 \mathrm{Ry}$. The BLYP functional was used $^{65,66}$ with Grimme's D3 dispersion correction ${ }^{67}$ and Becke-Johnson (BJ) for the DFT-D3 damping function, which was reported to reduce the error for reaction barriers in BLYP calculations. ${ }^{68}$ Small geometry and energy differences were established as compared to B3LYP (see Table S7 in the Supporting Information (SI)), which justifies the choice of the BLYP functional. The wave function optimization was carried out with the orbital transformation method, ${ }^{69}$ while the geometry of complexes was relaxed until forces converged below $0.02 \mathrm{eV} / \AA$ and the energy difference between subsequent self-consistent steps was less than $10^{-6} \mathrm{Ha}$. Calculations were carried out in periodic simulation boxes of dimensions $30 \times 30 \times 30 \AA$ that limit spurious interactions due to a distance of about $15 \AA$ between periodic images of the complexes. The $\mathrm{Ru}(\mathrm{II})$ ion is considered to be non-magnetic as a geometry optimized ferromagnetic complex with spin multiplicity 9 lies $1.6 \mathrm{eV}$ higher in energy. With this computational protocol, the geometry deviation was determined to be about $2.3 \%$ with respect to experiment (see Table S7 in SI).

All reaction mechanisms and their corresponding barriers were determined with the climbing image variant of the Nudged Elastic Band method. ${ }^{70}$ Each path was minimized until the energy difference converged below $0.002 \mathrm{eV}$.

The self-consistent continuum solvation model, SCCS, ${ }^{71}$ was used to implicitly account for the presence of a solvent. The cavity was defined as regions in the simulation cells with an electron density higher than $10^{-4} \mathrm{e} / \mathrm{Bohr}^{3}$, while the continuum region is defined for densities smaller than $10^{-5} \mathrm{e} / \mathrm{Bohr}^{3}$. The dielectric constants for dichloromethane and ethanol were set to 8.93 and 24.55 , respectively. No further geometry relaxation was performed for structures in implicit solvent. ${ }^{72}$

\section{EXPERIMENTAL SECTION}

General Experimental Considerations. Dichloro(p-cymene)ruthenium(II) dimer $\left[\left(\eta^{6}-p-\mathrm{MeC}_{6} \mathrm{H}_{4} \mathrm{Pr}^{i}\right) \mathrm{Ru}\left(\mu_{2}-\mathrm{Cl}\right) \mathrm{Cl}\right]_{2}$, p-nitrothiophenol (technical grade), cyclohexylthiol, thiophenol and DIPEA were purchased from Sigma Aldrich. $p$-methoxythiophenol was bought from Alfa Aesar. $\mathrm{CDCl}_{3}$ and $\mathrm{MeOD}$ were obtained from Cambridge Isotope Laboratories, $\mathrm{CD}_{2} \mathrm{Cl}_{2}$ was obtained from Eurisotop. Reactions were performed under protective atmosphere. NMR spectra were recorded on AVANCE III HD $300 \mathrm{MHz}$ with 5mm ATM BBFO probehead or AVANCE III HD $400 \mathrm{MHz}$ with 5mm ATM BBfO SmartProbe probehead, AVANCE II $400 \mathrm{MHz}$ with $5 \mathrm{~mm}$ ATM Dual probehead and AVANCE II $500 \mathrm{MHz}$ with $1.7 \mathrm{~mm}$ TXI $1 \mathrm{H}$ probehead, respectively. Unless specified otherwise NMR spectra were recorded at room temperature $\left(25^{\circ} \mathrm{C}\right)$ and processed using Topspin software.MS and elemental analysis were performed by the group of Prof. Stefan Schürch, University of Bern, using following set-up: LTQ Orbitrap XL with nano ESI (Thermo).

$\left[\left(\eta^{6}-p-\mathrm{MeC}_{6} \mathrm{H}_{4} \mathrm{Pr}^{i}\right)_{2} \mathrm{Ru}_{2}\left(\mu_{2}-\mathrm{SC}_{6} \mathrm{H}_{5}\right)_{3}\right]^{+} \mathrm{Cl}(\mathbf{1})$ was obtained from reaction of dichloro(p-cymene)ruthenium(II) dimer $\left[\left(\eta^{6}-p-\mathrm{MeC}_{6} \mathrm{H}_{4} \mathrm{Pr}^{i}\right) \mathrm{Ru}\left(\mu_{2-}\right.\right.$ $\mathrm{Cl}) \mathrm{Cl}]_{2}$ with thiophenol. ${ }^{34}$ Four different reaction conditions were applied. 1) $\left[\left(\eta^{6}-p-\mathrm{MeC}_{6} \mathrm{H}_{4} \mathrm{Pr}^{i}\right) \mathrm{Ru}\left(\mu_{2}-\mathrm{Cl}\right) \mathrm{Cl}\right](101.6 \mathrm{mg}, 0.166 \mathrm{mmol})$ was dissolved in EtOH abs. (45 mL) under reflux. Thiophenol $(75.6 \mathrm{mg}$, $0.686 \mathrm{mmol}, 4.1 \mathrm{eq})$ in EtOH abs. $(5 \mathrm{~mL})$ was slowly dropped into the refluxing solution and the mixture was left to react for $23 \mathrm{~h}$. After purification on silica column 1 was obtained as orange solid $(105.7 \mathrm{mg}$, $0.114 \mathrm{mmol}, 69 \%) .2)\left[\left(\eta^{6}-p-\mathrm{MeC}_{6} \mathrm{H}_{4} \mathrm{Pr}^{i}\right) \mathrm{Ru}\left(\mu_{2}-\mathrm{Cl}\right) \mathrm{Cl}\right]_{2} \quad(106.3 \mathrm{mg}$, $0.174 \mathrm{mmol})$ was dissolved in dry DCM $(45 \mathrm{~mL})$ and thereafter left to reflux. Thiophenol $(80.2 \mathrm{mg}, 0.728 \mathrm{mmol}, 4.2 \mathrm{eq})$ in dry DCM $(5 \mathrm{~mL})$ was added dropwise into the refluxing solution and left to react for $7 \mathrm{~h}$. After purification 1 was obtained as an orange solid $(127.4 \mathrm{mg}$, $0.138 \mathrm{mmol}, 62 \%)$. 3) $\left[\left(\eta^{6}-p-\mathrm{MeC}_{6} \mathrm{H}_{4} \mathrm{Pr}^{i}\right) \mathrm{Ru}\left(\mu_{2}-\mathrm{Cl}\right) \mathrm{Cl}\right]_{2}$ (106.6 mg, $0.174 \mathrm{mmol})$ was dissolved in dry DCM $(45 \mathrm{~mL})$ and left to reflux thereafter. Thiophenol $(81.4 \mathrm{mg}, 0.739 \mathrm{mmol}, 4.2 \mathrm{eq})$ in dry DCM $(5 \mathrm{~mL})$ was added dropwise and the reaction mixture was left to react for $1 \mathrm{~h}$. Next, the reaction mixture was cooled down in ice/water bath. DIPEA (69.6 mg, $0.539 \mathrm{mmol}, 3.1 \mathrm{eq})$ in dry DCM $(1 \mathrm{~mL})$ was added dropwise into cooled and stirred reaction mixture dropwise during $10 \mathrm{~min}$. Afterwards, the reaction mixture was heated again and left to react for further $1 \mathrm{~h} 50 \mathrm{~min}$ under reflux. Purification allowed 1 to be obtained as an orange solid (127.4 mg, $0.138 \mathrm{mmol}, 79 \%) .4)\left[\left(\eta^{6}-p\right.\right.$ $\left.\left.\mathrm{MeC}_{6} \mathrm{H}_{4} \mathrm{Pr}^{i}\right) \mathrm{Ru}\left(\mu_{2}-\mathrm{Cl}\right) \mathrm{Cl}\right]_{2}(101.4 \mathrm{mg}, 0.166 \mathrm{mmol})$ was dissolved in EtOH abs. (45 mL) under reflux. Thiophenol $(76.2 \mathrm{mg}, 0.692 \mathrm{mmol}$, $4.2 \mathrm{eq})$ in EtOH abs. (5 mL) was added dropwise into refluxing solution and reaction was left stirred. After 1h, DIPEA $(66.6 \mathrm{mg}, 0.515 \mathrm{mmol}$, $3.1 \mathrm{eq})$ in EtOH abs. (1 mL) was added slowly dropwise into refluxing mixture during $10 \mathrm{~min}$. The reaction was left to react for $1 \mathrm{~h} 50 \mathrm{~min}$. Purification allowed to obtain 1 as orange solid $(123.0 \mathrm{mg}, 0.132 \mathrm{mmol}$, $80 \%$ ). All three described reaction conditions employed $\mathrm{N}_{2}$ protective atmosphere. Reaction in $\mathrm{EtOH}$ were performed at $78-83^{\circ} \mathrm{C}$ while reactions in DCM were performed at $40-45^{\circ} \mathrm{C}$. For column chromatography $\mathrm{DCM} / \mathrm{EtOH}$ 10:1 was used. As needed in case of reaction performed in EtOH employing DIPEA, the product was further loaded on silica column with hexane/chloroform 100:1 and washed with gradient of hexane/chloroform, pure chloroform and finally released with DCM/EtOH 5:1. Analytical data for $\mathrm{C}_{38} \mathrm{H}_{43} \mathrm{~S}_{3} \mathrm{Ru}_{2} \mathrm{Cl} \cdot 2 \mathrm{EtOH}(925.67 \mathrm{~g} / \mathrm{mol}$ ) (Figure S21-23): Calculated: C, 54.50\%; H, 5.99\%. Found: C, 54.22\%; H, 6.26\%. ESI-MS (positive mode, $\mathrm{MeOH}) \mathrm{m} / z=799.1 .{ }^{1} \mathrm{H} \mathrm{NMR}\left(\mathrm{CDCl}_{3}\right.$, $400.1 \mathrm{MHz}): \delta_{\mathrm{H}} 7.89$ (6H, d, Ar H2, H6, J = 6.0 Hz), 7.39 (9H, m, Ar $\mathrm{H} 3, \mathrm{H} 4, \mathrm{H} 5), 5.41(2 \mathrm{H}, \mathrm{d}, \mathrm{H}-\mathrm{Ar} p$-cymene, J = 5.6 Hz), $5.24(2 \mathrm{H}, \mathrm{d}, \mathrm{H}-$ Ar $p$-cymene, $\mathrm{J}=5.6 \mathrm{~Hz}), 5.12(4 \mathrm{H}, \mathrm{m}, \mathrm{H}$-Ar $p$-cymene $), 1.92(2 \mathrm{H}$, sept, $\left.\mathrm{CH}\left(\mathrm{CH}_{3}\right)_{2}, \mathrm{~J}=6.9 \mathrm{~Hz}\right), 1.62\left(6 \mathrm{H}, \mathrm{s}, \mathrm{CH}_{3}\right), 0.89\left(6 \mathrm{H}, \mathrm{d}, \mathrm{CH}\left(\mathrm{CH}_{3}\right)_{2}\right.$, $\mathrm{J}=6.7 \mathrm{~Hz}), 0.77\left(6 \mathrm{H}, \mathrm{d}, \mathrm{CH}\left(\mathrm{CH}_{3}\right)_{2}, \mathrm{~J}=6.7 \mathrm{~Hz}\right) .{ }^{13} \mathrm{C} \mathrm{NMR}\left(\mathrm{CDCl}_{3}, 100\right.$ $\mathrm{MHz}$ ): $\delta_{\mathrm{C}} 137.8$ (thiol $\mathrm{C} 1$ ), 132.6 (thiol $\mathrm{C} 2 / \mathrm{C} 6$ ), 129.2 (thiol C3/C4/C5), 128.5 (thiol C3/C4/C5), 107.4 (C1 p-cymene), 100.0 (C4 p-cymene), 85.4 (C2/C3/C5/C6 p-cymene), 85.0 (C2/C3/C5/C6 p-cymene), 84.7 (C2/C3/C5/C6 p-cymene), 83.6 (C2/C3/C5/C6 p-cymene), $30.6\left(\underline{\mathbf{C H}}\left(\mathrm{CH}_{3}\right)_{2}\right), 22.5\left(\mathrm{CH}\left(\underline{\mathbf{C H}}_{3}\right)_{2}\right), 22.0\left(\mathrm{CH}\left(\underline{\mathbf{C H}}_{3}\right)_{2}\right), 17.7(\underline{\mathbf{C}} 3)$. 
$\left[\left(\eta^{6}-p-\mathrm{MeC}_{6} \mathrm{H}_{4} \mathrm{Pr}^{i}\right)_{2} \mathrm{Ru}_{2}\left(\mu_{2}-\mathrm{SC}_{6} \mathrm{H}_{4}-\mathrm{OMe}\right)_{3}\right]^{+} \mathrm{Cl}$ (2) was obtained from reaction of dichloro(p-cymene)ruthenium(II) dimer $\left[\left(\eta^{6}-p\right.\right.$ $\left.\left.\mathrm{MeC}_{6} \mathrm{H}_{4} \mathrm{Pr}^{i}\right) \mathrm{Ru}\left(\mu_{2}-\mathrm{Cl}\right) \mathrm{Cl}\right]_{2}$ with $p$-methoxythiophenol. [( $\eta^{6}-p$ $\left.\left.\mathrm{MeC}_{6} \mathrm{H}_{4} \mathrm{Pr}^{i}\right) \mathrm{Ru}\left(\mu_{2}-\mathrm{Cl}\right) \mathrm{Cl}\right]_{2}(100.6 \mathrm{mg}, 0.164 \mathrm{mmol})$ was dissolved in dry DCM $(45 \mathrm{~mL})$ under $\mathrm{N}_{2}$ atmosphere and heated to reflux at 38 $45^{\circ} \mathrm{C}$. $p$-methoxythiophenol $(92.4 \mathrm{mg}, 0.659 \mathrm{mmol}, 4.0 \mathrm{eq})$ in dry DCM $(5 \mathrm{~mL})$ was added dropwise into refluxing solution and it was left to react for $9 \mathrm{~h}$. Purification on silica column employing DCM/EtOH 5:1 as mobile phase allowed to obtain $\mathbf{2}$ as an orange solid (115.7 $\mathrm{mg}, \quad 0.121 \mathrm{mmol}, \quad 73 \%)$. Analytical data for $\mathrm{C}_{41} \mathrm{H}_{49} \mathrm{O}_{3} \mathrm{Ru}_{2} \mathrm{~S}_{3} \mathrm{Cl} \cdot 2 \mathrm{H}_{2} \mathrm{O}$ (959.64 g/mol) (Figure S24-26): Calculated: C, 51.32\%; H, 5.57\%. Found: C, 51.58\%; H, 5.70\%. ESI-MS (positive mode, $\mathrm{MeOH}): m / z$ 889.1. ${ }^{1} \mathrm{H}$ NMR $\left(\mathrm{CD}_{2} \mathrm{Cl}_{2}, 400 \mathrm{MHz}\right): \delta_{\mathrm{H}} 7.79(6 \mathrm{H}$, d, H-Ar thiol, $\mathrm{J}=8.8 \mathrm{~Hz}), 6.91(6 \mathrm{H}, \mathrm{d}, \mathrm{H}-\mathrm{Ar}$ thiol, $\mathrm{J}=8.8 \mathrm{~Hz}),$, $(2 \mathrm{H}, \mathrm{d}, \mathrm{H}$-Ar $p$-cymene, $\mathrm{J}=5.8 \mathrm{~Hz}), 5.18(2 \mathrm{H}, \mathrm{d}, \mathrm{H}$-Ar $p$-cymene, $\mathrm{J}=$ $5.8 \mathrm{~Hz}), 5.08\left(4 \mathrm{H}, \mathrm{m}, \mathrm{H}-\mathrm{Ar} p\right.$-cymene), $3.86\left(9 \mathrm{H}, \mathrm{s}, \mathrm{OCH}_{3}\right), 1.96(2 \mathrm{H}$, sept, $\left.\mathrm{CH}\left(\mathrm{CH}_{3}\right)_{2}, \mathrm{~J}=6.9 \mathrm{~Hz},\right), 1.61\left(6 \mathrm{H}, \mathrm{s}, \mathrm{CH}_{3} p\right.$-cymene), $0.91(6 \mathrm{H}, \mathrm{d}$, $\left.\mathrm{CH}\left(\mathrm{CH}_{3}\right)_{2}, \mathrm{~J}=6.9 \mathrm{~Hz}\right), 0.81\left(6 \mathrm{H}, \mathrm{d}, \mathrm{CH}\left(\mathrm{CH}_{3}\right)_{2}, \mathrm{~J}=6.9 \mathrm{~Hz}\right) .{ }^{13} \mathrm{C} \mathrm{NMR}$ $\left(\mathrm{CD}_{2} \mathrm{Cl}_{2}, 100 \mathrm{MHz}\right): \delta_{\mathrm{C}} 160.1,133.7,128.6,114.5,107.3,99.5,85.3$, 84.7, 84.4, 83.5, 55.5, 30.6, 22.2, 21.8, 17.5.

$\left[\left(\eta^{6}-p-\mathrm{MeC}_{6} \mathrm{H}_{4} \mathrm{Pr}^{i}\right)_{2} \mathrm{Ru}_{2}\left(\mu_{2}-\mathrm{SC}_{6} \mathrm{H}_{4}-\mathrm{NO}_{2}\right)_{3}\right]^{+} \mathrm{Cl}(3)$ was obtained from reaction of dichloro(p-cymene)ruthenium(II) dimer $\left[\left(\eta^{6}-p\right.\right.$ $\left.\left.\mathrm{MeC}_{6} \mathrm{H}_{4} \mathrm{Pr}^{i}\right) \mathrm{Ru}\left(\mu_{2}-\mathrm{Cl}\right) \mathrm{Cl}\right]_{2}$ with $p$-nitrothiophenol. $\quad\left[\left(\eta^{6}-p\right.\right.$ $\left.\left.\mathrm{MeC}_{6} \mathrm{H}_{4} \mathrm{Pr}^{i}\right) \mathrm{Ru}\left(\mu_{2}-\mathrm{Cl}\right) \mathrm{Cl}\right]_{2}(101.6 \mathrm{mg}, 0.166 \mathrm{mmol})$ was dissolved in dry DCM $(40 \mathrm{~mL})$ under $\mathrm{N}_{2}$ atmosphere and heated to reflux at 40 $45^{\circ} \mathrm{C}$. $80 \%$ technical grade $p$-nitrothiophenol $(128.7 \mathrm{mg}, 0.664 \mathrm{mmol}$, $4.0 \mathrm{eq})$ in dry DCM $(10 \mathrm{~mL})$ was added dropwise into the refluxing solution. After 30-60min after addition of the thiol the mixture turned slowly dark red. The reaction was left to react for $2 \mathrm{~h}$ in total. Purification on silica column using DCM/EtOH 5:1 as an eluent allowed 3 to be isolated as a red solid $(125.8 \mathrm{mg}, 0.121 \mathrm{mmol}, 73 \%)$. An alternative approach employing an organic base was tested: $\left[\left(\eta^{6}-p\right.\right.$ $\left.\left.\mathrm{MeC}_{6} \mathrm{H}_{4} \mathrm{Pr}^{i}\right) \mathrm{Ru}\left(\mu_{2}-\mathrm{Cl}\right) \mathrm{Cl}\right]_{2}(99.1 \mathrm{mg}, 0.161 \mathrm{mmol})$ was dissolved in dry DCM $(40 \mathrm{~mL})$ under $\mathrm{N}_{2}$ and heated to reflux. $p$-nitrothiophenol (150.1 mg, $0.967 \mathrm{mmol}, 6.0 \mathrm{eq}$ ) was added dropwise into refluxing solution. After $1 \mathrm{~h}$, the heating was stopped and DIPEA $(69.1 \mathrm{mg}$, $0.535 \mathrm{mmol}, 3.3 \mathrm{eq}$ ) has been added dropwise into temperature-regulated stirred reaction mixture. Afterwards, the mixture was left to react for further $1 \mathrm{~h}$ under reflux, but progressively turned black indicating starting material decomposition. This approach has been abandoned. Analytical data for $\mathrm{C}_{38} \mathrm{H}_{40} \mathrm{~N}_{3} \mathrm{O}_{6} \mathrm{~S}_{3} \mathrm{Ru} 2 \mathrm{Cl} \cdot 6 / 7 \mathrm{DCM}(1041.32 \mathrm{~g} / \mathrm{mol})$ (Figure S27-29): ESI-MS (positive mode, $\mathrm{MeOH}$ ): $\mathrm{m} / \mathrm{z}$ 934.0. Calculated: C, $44.82 \%$; H, 4.04\%. Found: C, $45.03 \%$; H, 3.74\%. ${ }^{1} \mathrm{H}$ NMR (MeOD, $400.1 \mathrm{MHz}): \delta_{\mathrm{H}} 8.25(12 \mathrm{H}, \mathrm{ABq}, \mathrm{H}-\mathrm{Ar}$ thiol, $\mathrm{J}=8.9 \mathrm{~Hz}), 5.76$ (2H, d, H-Ar p-cymene, $5.7 \mathrm{~Hz}), 5.63(2 \mathrm{H}, \mathrm{d}, \mathrm{H}-\mathrm{Ar} p$-cymene, $5.7 \mathrm{~Hz})$, $5.43(4 \mathrm{H}, \mathrm{m}, \mathrm{H}$-Ar $p$-cymene $), 1.99\left(2 \mathrm{H}\right.$, sept, $\left.\mathrm{CH}\left(\mathrm{CH}_{3}\right)_{2}, \mathrm{~J}=6.9 \mathrm{~Hz}\right)$, $1.67\left(6 \mathrm{H}, \mathrm{s}, \mathrm{CH}_{3} p\right.$-cymene), $0.92\left(6 \mathrm{H}, \mathrm{d}, \mathrm{CH}\left(\mathrm{CH}_{3}\right)_{2}, \mathrm{~J}=6.9 \mathrm{~Hz}\right), 0.80$ $\left(6 \mathrm{H}, \mathrm{d}, \mathrm{CH}\left(\mathrm{CH}_{3}\right)_{2}, \mathrm{~J}=6.9 \mathrm{~Hz}\right) .{ }^{13} \mathrm{C} \mathrm{NMR}(\mathrm{MeOD}, 400.1 \mathrm{MHz}): \delta_{\mathrm{C}}$ 147.8 (thiol C1/C4), 146.8 (thiol C1/C4), 133.7 (thiol C2/C3/C5/C6), 123.6 (thiol $\mathrm{C} 2 / \mathrm{C} 3 / \mathrm{C} 5 / \mathrm{C} 6$ ), 108.3 (C1 p-cymene), 101.1 (C4 p-cymene), 85.8 (C2/C3/C5/C6 p-cymene), 85.8 (C2/C3/C5/C6 $p$-cymene), 85.5 (C2/C3/C5/C6 p-cymene), 85.0 (C2/C3/C5/C6 p-cymene), 30.9 $\left(\underline{\mathbf{C H}}\left(\mathrm{CH}_{3}\right)_{2}\right), 21.4\left(\mathrm{CH}\left(\underline{\mathbf{C H}}_{3}\right)_{2}\right), 20.7\left(\mathrm{CH}\left(\underline{\mathbf{C H}}_{3}\right)_{2}\right), 16.5(\underline{\mathbf{C H}} 3)$.

$\left[\left(\eta^{6}-p-\mathrm{MeC}_{6} \mathrm{H}_{4} \mathrm{Pr}^{i}\right)_{2} \mathrm{Ru}_{2}\left(\mu_{2}-\mathrm{SC}_{6} \mathrm{H}_{11}\right)_{3}\right]^{+} \mathrm{Cl}(\mathbf{4})$ was obtained from reaction of dichloro(p-cymene)ruthenium(II) dimer $\left[\left(\eta^{6}-p\right.\right.$ $\left.\left.\mathrm{MeC}_{6} \mathrm{H}_{4} \mathrm{Pr}^{i}\right) \mathrm{Ru}\left(\mu_{2}-\mathrm{Cl}\right) \mathrm{Cl}\right]_{2} \quad$ with cyclohexanethiol. $\quad\left[\left(\eta^{6}-p-\right.\right.$ $\left.\left.\mathrm{MeC}_{6} \mathrm{H}_{4} \mathrm{Pr}^{i}\right) \mathrm{Ru}\left(\mu_{2}-\mathrm{Cl}\right) \mathrm{Cl}\right]_{2}(100 \mathrm{mg}, 0.163 \mathrm{mmol})$ was dissolved in dry DCM $(40 \mathrm{~mL})$ under $\mathrm{Ar}$ and heated to reflux. Cyclohexanethiol (166.5 mg, $1.433 \mathrm{mmol}, 8.8 \mathrm{eq})$ in dry DCM $(10 \mathrm{~mL})$ was added dropwise into refluxing solution and reaction mixture was left to react for 18h. As a next step, DIPEA ( $86.0 \mathrm{mg}, 0.665 \mathrm{mmol}, 4.1 \mathrm{eq})$ in dry DCM $(5 \mathrm{~mL})$ was added slowly into the solution during 5-10 min. The mixture was left to react for further 6 days. Three-step purification on silica column was applied. First, the product was pre-purified on silica column using DCM/EtOH 5:1 as a mobile phase. The orange fraction has been concentrated and further purified on silica column using $\mathrm{CHCl} 3 /$ acetone 3:2 as an eluent. Finally, concentrate of fractions containing the product was purified on silica column using gradient elution system of acetone with increasing amount of $10 \%$ acetic acid up to $1: 1$ ratio to obtain 4 as viscous orange brown matter $(30 \mathrm{mg})$. The product contained impurities. Due to nature and amount of the product no thermal analysis could be done. Analytical data for $\left[\left(\eta^{6}-p-\right.\right.$ $\left.\left.\mathrm{MeC}_{6} \mathrm{H}_{4} \mathrm{Pr}^{i}\right)_{2} \mathrm{Ru}_{2}\left(\mu_{2}-\mathrm{SC}_{6} \mathrm{H}_{11}\right)_{3}\right]^{+} \mathrm{Cl} \quad(851.67 \mathrm{~g} / \mathrm{mol})$ (Figure $\left.\mathrm{S} 31-34\right)$ : ESI-MS (positive mode, $\mathrm{MeOH}): \mathrm{m} / z=817.2 .{ }^{1} \mathrm{H} \mathrm{NMR}(400.1 \mathrm{MHz}$, $\mathrm{CDCl} 3)$ : 5.48 (4H, m, Ar $p$-cymene), 5.35 (2H, m, Ar $p$-cymene, $\mathrm{J}=5.0$ $\mathrm{Hz}), 5.29(2 \mathrm{H}, \mathrm{d}, \mathrm{Ar}$-cymene, $\mathrm{J}=5.0 \mathrm{~Hz}), 2.57\left(2 \mathrm{H}\right.$, sept, $\mathrm{C} \underline{\mathbf{H}}\left(\mathrm{CH}_{3}\right)_{2}$, $\mathrm{J}=6.7 \mathrm{~Hz}), 2.37(6 \mathrm{H}, \mathrm{m}, \mathrm{H} 1 \mathrm{thiol}), 2.21\left(6 \mathrm{H}, \mathrm{s}, \mathrm{CH}_{3}\right), 1.73(6 \mathrm{H}, \mathrm{m}$, thiol), $1.51\left(6 \mathrm{H}, \mathrm{m}\right.$, thiol), $1.39\left(6 \mathrm{H}, \mathrm{m}\right.$, thiol), $1.31\left(6 \mathrm{H}, \mathrm{d}, \mathrm{CH}\left(\mathrm{CH}_{3}\right)_{2}\right.$, $\mathrm{J}=6.7 \mathrm{~Hz}), 1.26\left(6 \mathrm{H}, \mathrm{d}, \mathrm{CH}\left(\mathrm{CH}_{3}\right)_{2}, \mathrm{~J}=6.7 \mathrm{~Hz}\right), 0.96(9 \mathrm{H}, \mathrm{m}$, thiol $)$. ${ }^{13} \mathrm{C}$ NMR ( $\left.\mathrm{CDCl}_{3}, 100 \mathrm{MHz}\right): 106.5$ (C1 p-cymene), 101.4 (C4 p-cymene), 83.7 (C2/C3/C5/C6 p-cymene), 83.2 (C2/C3/C5/C6 p-cymene), 83.1 (C2/C3/C5/C6 p-cymene), 82.9 (C2/C3/C5/C6 p-cymene), 39.0 (thiol), 32.8 (thiol), $31.6\left(\underline{\mathrm{CH}}\left(\mathrm{CH}_{3}\right)_{2}+\right.$ thiol), 28.9 (thiol), 24.0 $\left(\mathrm{CH}\left(\mathrm{CH}_{3}\right)_{2}\right), 22.6$ (thiol), $22.4\left(\mathrm{CH}\left(\underline{\mathbf{C H}}_{3}\right)_{2}\right), 18.3\left(\mathrm{CH}_{3}\right), 14.1$ (thiol). Reaction kinetics by NMR for the reaction conditions at $0^{\circ} \mathrm{C}$ or $25^{\circ} \mathrm{C}$ : $\left[\left(\eta^{6}-p-\mathrm{MeC}_{6} \mathrm{H}_{4} \mathrm{Pr}^{i}\right) \mathrm{Ru}\left(\mu_{2}-\mathrm{Cl}\right) \mathrm{Cl}\right]_{2}$ was dissolved in $\mathrm{CD}_{2} \mathrm{Cl}_{2}(500 \mu \mathrm{L})$ in NMR tube closed with septum and flushed with stream of $\mathrm{N}_{2}$. Next, corresponding amount of thiol $(4 \mathrm{eq})$ in $\mathrm{CD}_{2} \mathrm{Cl}_{2}(300 \mu \mathrm{L})$ was injected into the tube. The tube was immediately placed into the spectrometer and NMR measurements were started at spinning rate of $10 \mathrm{~Hz}$. (In case of measurements at $0^{\circ} \mathrm{C}$ the spectrometer was pre-cooled and ice-cold $\mathrm{CD}_{2} \mathrm{Cl}_{2}$ was used for the sample preparation.) The amounts of $\left[\left(\eta^{6}-p-\right.\right.$ $\left.\mathrm{MeC}_{6} \mathrm{H}_{4} \mathrm{Pr}^{i}\right) \mathrm{Ru}\left(\mu_{2}-\mathrm{Cl}\right) \mathrm{Cl}_{2}$ and thiol used are summarized in Table 2. Processed ${ }^{1} \mathrm{H}$ NMR spectra were transferred to Dynamic Center where normalized integrals of signals of interest were plotted and fitted with built-in functions to find an optimal fit in order to obtain $k^{54-56}$ The reaction in DCM at $45^{\circ} \mathrm{C}$ could not be followed directly by NMR (due to low boiling point of DCM). Instead, aliquots of the reaction mixture were collected at different time points and transferred into $\mathrm{CDCl}_{3}$ for the measurement. As a result, only limited and rather low number of time points could be obtained which could not be used to obtain $k$, but only as a slight hint on how fast the reaction proceeds at this temperature (Figure S9-10, 17-18, 34-35)

Table 2. Reaction rate constants for the first two steps calculated from the constants of the individual steps or determined experimentally from NMR kinetic data, respectively.

\begin{tabular}{|l|l|l|l|l|}
\hline \multirow{2}{*}{$\mathrm{R}$} & \multicolumn{2}{l|}{ Ru dimer $(\mathrm{mg})$} & \multicolumn{2}{l|}{ Thiol $(\mathrm{mg})$} \\
\cline { 2 - 5 } & $\mathrm{mg}$ & $\mu \mathrm{mol}$ & $\mathrm{mg}$ & $\mu \mathrm{mol}$ \\
\hline $\mathrm{C}_{6} \mathrm{H}_{5}\left(0^{\circ} \mathrm{C}\right)$ & 2.1 & 3.4 & 1.5 & 13.6 \\
\hline $\mathrm{C}_{6} \mathrm{H}_{5}\left(25^{\circ} \mathrm{C}\right)$ & 2.0 & 3.3 & 1.5 & 13.6 \\
\hline $\mathrm{C}_{6} \mathrm{H}_{4} \mathrm{NO}_{2}\left(0^{\circ} \mathrm{C}\right)$ & 2.0 & 3.3 & 2.6 & 13.4 \\
\hline $\mathrm{C}_{6} \mathrm{H}_{4} \mathrm{NO}_{2}\left(25^{\circ} \mathrm{C}\right)$ & 2.1 & 3.4 & 2.7 & 13.9 \\
\hline $\mathrm{C}_{6} \mathrm{H}_{4} \mathrm{OMe}$ & 2.0 & 3.3 & 1.9 & 13.6 \\
\hline $\mathrm{C}_{6} \mathrm{H}_{11}$ & 2.0 & 3.3 & 1.6 & 13.8 \\
\hline
\end{tabular}

\section{ASSOCIATED CONTENT}

\section{Supporting Information}

The Supporting Information is available free of charge on the ACS Publications website.

The supporting Information contains numerical values of the transition-state barriers and NEB reaction pathways; comparison between the DFT geometries with BLYP and B3LYP of the Ru dimer; NMR and MS spectra; NMR-based kinetics of formation graphs for all complexes.

\section{AUTHOR INFORMATION}




\section{Corresponding Authors}

* Julien Furrer, Ulrich Aschauer

Tel. +41 (0) 316314383

Fax +41(0) 316314887

E-mail: julien.furrer@dcb.unibe.ch (J. Furrer); ulrich.aschauer@dcb.unibe.ch (U. Aschauer)

\section{ACKNOWLEDGMENT}

This research was funded by the SNF Professorship Grant PP00P2_157615. Calculations were performed on UBELIX (http://www.id.unibe.ch/hpc), the HPC cluster at the University of Bern.

\section{REFERENCES}

(1) Yanhui Chen, Ying Peng, Pingping Chen, Jinfeng Zhao, Litao Liu, Yang Li, S. C. and J. Q. Insertion Reactions of CS2, COS, and PhNCS at Thiolate-Bridged Diiron Centers. Dalt. Trans. 2010, 39 (12), 3020-3025. https://doi.org/10.1039/b922606k. Chen, Y.; Zhou, Y.; Chen, P.; Tao, Y.; Li, Y.; Qu, J.; Me, R.; Ph, R.; Et, R. Nitrogenase Model Complexes $[\mathrm{Cp} * \mathrm{Fe}(\mu-\mathrm{SR} 1) 2(\mu-$ $\left.\mathrm{H} 2 \mathrm{~N}=\mathrm{NH}) \mathrm{FeCp}^{*}\right]\left(\mathrm{R} 1=\mathrm{Me}, \mathrm{Et} ; \mathrm{R} 2=\mathrm{Me}, \mathrm{Ph} ; \mathrm{Cp}^{*}=\mathrm{H} 5\right.$ C5Me5): Synthesis, Structure, and Catalytic N-N Bond Cleavage of Hydrazines on Diiron Centers. J. Am. Chem. Soc. 2008, 2 (Table 1), 15250-15251.

(3) Chen, Y.; Zhou, Y.; Qu, J. Synthesis and Reactions of Novel Triply Thiolate-Bridged Diiron Complexes [Cp*Fe(M2SR)3FeCp*] $\left(\mathrm{Cp}^{*}=\mathrm{H} 5-\mathrm{C} 5 \mathrm{Me} 5 ; \mathrm{R}=\mathrm{Et}, \mathrm{Ph}\right)$. Organometallics 2008, 27 (4), 666-671. https://doi.org/10.1021/om0611148. Zhao, J.; Wang, L.; Zhou, Y.; Zhang, Y.; Zhang, N.; Jia, C.; Hu, F.; Chen, Y.; Wang, B.; Qu, J. Synthesis, Structure and Reactions of Triply Selenolate-Bridged Diiron Complex $[\mathrm{Cp} * \mathrm{Fe}(\mu-$ $\mathrm{SeMe} 3 \mathrm{FeCp} *$. Inorg. Chem. Commun. 2013, 29, 179-182. https://doi.org/10.1016/j.inoche.2012.12.031.

(5) Gupta, G.; Nagesh, N.; Murray, B. S.; Dyson, P. J.; Therrien, B. Antiproliferative Activities of Trithiolato-Bridged Dinuclear Arene Osmium Complexes. Inorganica Chim. Acta 2014, 423 (PART A), 31-35. https://doi.org/10.1016/j.ica.2014.07.050.

(6) Boudreau, J.; Grenier-Desbiens, J.; Fontaine, F.-G. MS-TOF Study of the Formation of Thiolato-Bridged Rhodium Oligomers. Eur. J. Inorg. Chem. 2010, 2010 (14), 2158-2164. https://doi.org/10.1002/ejic.200901201.

(7) Takagi, F.; Seino, H.; Hidai, M.; Mizobe, Y. Preparation of a Heterobimetallic Cluster with Bridging Sulfido and Thiolato Ligands [\{(H5-C5Me5)Ru $\}\{(\mathrm{H} 5-\mathrm{C} 5 \mathrm{Me} 5) \mathrm{Ir}\} 2(\mathrm{M} 3-\mathrm{S})(\mathrm{M} 2-\mathrm{SCH}$ $2 \mathrm{CH} 2 \mathrm{CN}) 2 \mathrm{Cl}]$ and Its Transformations into Alkyne, CO, Isocyanide, and Iminoacyl Clusters. Organometallics 2003, 22 (5), 1065-1071. https://doi.org/10.1021/om0208117.

Fusao Takagi, Hidetake Seino, Yasushi Mizobe, M. H. Addition of Bridging-Hydrosulfido Ligands in Diiridium Complex to Acrylonitrile. Synthesis of Diiridium Cyanoethylthiolato Complexes and RuIr2 Sulfido-Cyanoethylthiolato Cluster. Can. J. Chem. 2001, 79 (5-6), 632-634.

(9) Takagi, F.; Seino, H.; Mizobe, Y.; Hidai, M. Synthesis of a New Tetrakis(Hydrosulfido) Diiridium Complex and Its Conversion into Homo- and Heterometallic Sulfido-Hydrosulfido Clusters. $\begin{array}{lllll}\text { Organometallics 2002, } & 21 & \text { (4), } & \text { 694-699. }\end{array}$ https://doi.org/10.1021/om0108550.

(10) Gupta, G.; Garci, A.; Murray, B. S.; Dyson, P. J.; Fabre, G.; Trouillas, P.; Giannini, F.; Furrer, J.; Süss-Fink, G.; Therrien, B. Synthesis, Molecular Structure, Computational Study and in Vitro Anticancer Activity of Dinuclear Thiolato-Bridged Pentamethylcyclopentadienyl Rh(Iii) and Ir(Iii) Complexes. Dalt. Trans. 2013, 42 (43), 15457-15463. https://doi.org/10.1039/c3dt51991k.

(11) Johnpeter, J. P.; Gupta, G.; Kumar, J. M.; Srinivas, G.; Nagesh, N.; Therrien, B. Biological Studies of Chalcogenolato-Bridged Dinuclear Half-Sandwich Complexes. Inorg. Chem. 2013, 52 (23), 13663-13673. https://doi.org/10.1021/ic4022307.

(12) Gupta, G.; Murray, B. S.; Dyson, P. J.; Therrien, B. Highly Cytotoxic Trithiolato-Bridged Dinuclear $\mathrm{Rh}(\mathrm{III})$ and $\operatorname{Ir}(\mathrm{III})$
Complexes. J. Organomet. Chem. 2014, 767, 78-82. https://doi.org/10.1016/j.jorganchem.2014.05.021.

Gras, M.; Therrien, B.; Süss-Fink, G.; Zava, O.; Dyson, P. J. Thiophenolato-Bridged Dinuclear Arene Ruthenium Complexes: A New Family of Highly Cytotoxic Anticancer Agents. Dalt. Trans. 2010, 39 (42), 10305-10313. https://doi.org/10.1039/c0dt00887g.

(14) Süss-Fink, G. Arene Ruthenium Complexes as Anticancer Agents. Dalt. Trans. 2010, 39 (7), 1673-1688. https://doi.org/10.1039/b916860p.

(15) Giannini, F.; Bartoloni, M.; Paul, L. E. H.; Süss-Fink, G.; Reymond, J. L.; Furrer, J. Cytotoxic Peptide Conjugates of Dinuclear Arene Ruthenium Trithiolato Complexes. Medchemcomm 2015, $6 \quad$ (2), 347-350 https://doi.org/10.1039/c4md00433g.

(16) Giannini, F.; Geiser, L.; Paul, L. E. H.; Roder, T.; Therrien, B.; Süss-Fink, G.; Furrer, J. Tuning the in Vitro Cell Cytotoxicity of Dinuclear Arene Ruthenium Trithiolato Complexes: Influence of the Arene Ligand. J. Organomet. Chem. 2015, 783, 40-45. https://doi.org/10.1016/j.jorganchem.2015.02.010.

(17) Tomšík, P.; Muthná, D.; Řezáčová, M.; Mičuda, S.; Ćmielová, J.; Hroch, M.; Endlicher, R.; Červinková, Z.; Rudolf, E.; Hann, S.; et al. [(P-MeC6H4Pri)2Ru2(SC6H4-p-But)3]Cl (Diruthenium1), a Dinuclear Arene Ruthenium Compound with Very High Anticancer Activity: An in Vitro and in Vivo Study. $J$. Organomet. Chem. 2015, 782, 42-51. https://doi.org/10.1016/j.jorganchem.2014.10.050.

(18) Furrer, J.; Süss-Fink, G. Thiolato-Bridged Dinuclear Arene Ruthenium Complexes and Their Potential as Anticancer Drugs. Coord. Chem. Rev. 2016, 309, 36-50 https://doi.org/10.1016/j.ccr.2015.10.007.

(19) Basto, A. P.; Müller, J.; Rubbiani, R.; Stibal, D.; Giannini, F.; Süss-Fink, G.; Balmer, V.; Hemphill, A.; Gasser, G.; Furrer, J. Characterization of the Activities of Dinuclear Thiolato-Bridged Arene Ruthenium Complexes against Toxoplasma Gondii. Antimicrob. Agents Chemother. 2017, 61 (9), e01031-17.

(20) Basto, A. P.; Anghel, N.; Rubbiani, R.; Müller, J.; Stibal, D.; Giannini, F.; Süss-Fink, G.; Balmer, V.; Gasser, G.; Furrer, J.; et al. Targeting of the Mitochondrion by Dinuclear ThiolatoBridged Arene Ruthenium Complexes in Cancer Cells and in the Apicomplexan Parasite Neospora Caninum. Metallomics 2019, 11, 462-474. https://doi.org/10.1039/c8mt00307f.

(21) Giannini, F.; Süss-Fink, G.; Furrer, J. Efficient Oxidation of Cysteine and Glutathione Catalyzed by a Dinuclear Areneruthenium Trithiolato Anticancer Complex. Inorg. Chem. 2011, 50 (21), 10552-10554. https://doi.org/10.1021/ic201941j.

(22) Giannini, F.; Furrer, J.; Ibao, A. F.; Süss-Fink, G.; Therrien, B.; Zava, O.; Baquie, M.; Dyson, P. J.; Štěpnička, P. Highly Cytotoxic Trithiophenolatodiruthenium Complexes of the Type [(H6-p-MeC6H4Pr i ) 2Ru2(SC6H4-p-X)3] +: Synthesis, Molecular Structure, Electrochemistry, Cytotoxicity, and Glutathione Oxidation Potential. J. Biol. Inorg. Chem. 2012, 17 (6), 951-960. https://doi.org/10.1007/s00775-012-0911-2.

(23) F. Giannini, L. E. H. Paul, J. F. Insights into the Mechanism of Action and Cellular Targets of Ruthenium Complexes from NMR Spectroscopy. Chimia (Aarau). 2012, 66, 775-780.

(24) Giannini, F.; Furrer, J.; Süss-fink, G.; Clavel, C. M. Synthesis Characterization and in Vitro Anticancer Activity of Highly Cytotoxic Trithiolato Diruthenium Complexes of the Type. $J$. Organomet. Chem. 2013, 744, 41-48.

(25) Giannini, F.; Paul, L. E. H.; Furrer, J.; Therrien, B.; Süss-Fink, G. Highly Cytotoxic Diruthenium Trithiolato Complexes of the Type [(H6-p-MeC6H4Pri)2Ru2(M2-SR)3]+: Synthesis, Characterization, Molecular Structure and in Vitro Anticancer Activity. New J. Chem. 2013, 37 (11), 3503-3511. https://doi.org/10.1039/c3nj00476g.

(26) Gomes de Lima, M. B.; Guerchais, J. E.; Pétillon, F. Y.; Mercier, R. Reactions of Bimetallic Group VI (6) Complexes. 3. Synthesis, Characterization, and Reactivity of Dimeric Molybdenum(III) and Tungsten(III) Compounds with Bridging Thiolate Ligands. A Molybdenum-95 NMR Study on Dinuclear Molybdenum Complexes. Crystal Stru. Organometallics 1986, 5 (10), 1952 1964. https://doi.org/10.1021/om00141a005. 
Pétillon, F. Y.; Schollhammer, P.; Talarmin, J.; Muir, K. W. Dinuclear Molybdenum Thiolato-Bridged Compounds: Syntheses, Reactivities and Electrochemical Studies of SiteSubstrate Interactions. Coord. Chem. Rev. 1998, 178-180, 203247. https://doi.org/10.1016/s0010-8545(98)00151-9.

Pétillon, F. Y.; Schollhammer, P.; Talarmin, J. Recent Advances in the Chemistry of Tris(Thiolato) Bridged Cyclopentadienyl Dimolybdenum Complexes. Coord. Chem. Rev. 2017, 331, 7392. https://doi.org/10.1016/j.ccr.2016.10.004.

(30) Zelonka, R. A.; Baird, M. C. Reactions of $\pi$ Benzeneruthenium(II) Complexes with Alkylating Reagents. $J$. Organomet. Chem. 1972, 44 (2), 383-389.

(31) Zelonka, R. A.; Baird, M. C. Reactions of Benzene Complexes of Ruthernium(II). J. Organomet. Chem. 1972, 35 (1), C43-C46.

(32) Zelonka, R. A.; Baird, M. C. Benzene Complexes of Ruthenium(II). Can. J. Chem. 1972, 50 (18), 3063-3072. https://doi.org/10.1139/v72-486.

(33) Schacht, H. T.; Haltiwanger, R. C.; DuBois, M. R. Structural Characterization of [((Hexamethylbenzene $) \mathrm{Ru}) 2(\varepsilon-\mathrm{SPh}) 3] \mathrm{CI}-$ 2HCl3. Inorg. Chem. 1992, 31 (9), 1728-1730. https://doi.org/10.1021/ic00035a042.

(34) Mashima, K.; Mikami, A.; Nakamura, A. Preparation and Structural Characterization of Cationic Dinuclear Ruthenium(II) - Thiolate Complexes, [Ru2(SPh)3(H6-p-Cymene)2] Y (Y = Cl and PF6). Chem. Lett. 1992, 21 (9), 1795-1798. https://doi.org/10.1246/cl.1992.1795.

(35) Stíbal, D.; Geiser, L.; Süss-Fink, G.; Furrer, J. Hydrolytic Behaviour of Mono- and Dithiolato-Bridged Dinuclear Arene Ruthenium Complexes and Their Interactions with Biological Ligands. $\quad R S C$ Adv. 2016, $6 \quad$ (44), $38332-38341$. https://doi.org/10.1039/c6ra07701c.

(36) Chérioux, F.; Thomas, C. M.; Monnier, T.; Süss-Fink, G. Specific Reactivity of SH versus OH Functions towards Dinuclear Arene Ruthenium Units: Synthesis of Cationic Complexes of the Type [(Arene)2Ru2(SR)3]+. Polyhedron 2003, 22 (4), 543-548. https://doi.org/10.1016/S0277-5387(02)01376-1.

(37) Chérioux, F.; Therrien, B.; Süss-Fink, G. Synthesis and Structural Characterisation of New Cationic Dinuclear Ruthenium(II) Thiolato Complexes of the Type [Ru2( $\eta$ 6-Arene)2( $\mu$-p-S-C6H4$\mathrm{Br}$ ) 3]+. Inorganica Chim. Acta 2004, 357 (3), 834-838. https://doi.org/10.1016/j.ica.2003.09.006.

(38) Süss-Fink, G.; Therrien, B. Dinuclear Ruthenium and Osmium Arene Trihydrido Complexes: Versatile Water-Soluble Synthons in Organometallic Chemistry. Organometallics 2007, 26 (4), 766-774. https://doi.org/10.1021/om060747j.

(39) Dyson, P. J.; Süss-Fink, G.; Giannini, F.; Furrer, J.; Clavel, C. M. Synthesis, Characterization and in Vitro Anticancer Activity of Highly Cytotoxic Trithiolato Diruthenium Complexes of the Type [(H6-p-MeC6H4iPr)2Ru2(M2-SR1)2(M2-SR2)]+ Containing Different Thiolato Bridges. J. Organomet. Chem. 2013, 744, 41-48. https://doi.org/10.1016/j.jorganchem.2013.04.049.

(40) Chérioux, F.; Thomas, C. M.; Therrien, B.; Süss-Fink, G. Dendritic Systems Based on Dinuclear Ruthenium or Rhodium Units Generating Peripheral Catalytic Sites. Chem. - A Eur. J. 2002, 8 (19), 4377-4382. https://doi.org/10.1002/15213765(20021004)8:19<4377::AID-CHEM4377>3.0.CO;2-G.

(41) Hartinger, C. G.; Jakupec, M. A.; Zorbas-Seifried, S.; Groessl, M.; Egger, A.; Berger, W.; Zorbas, H.; Dyson, P. J.; Keppler, B. K. KP1019, A New Redox-Active Anticancer Agent - Preclinical Development and Results of a Clinical Phase I Study in Tumor Patients. Chem. Biodivers. 2008, 5 (10), 2140-2155.

(42) Antonarakis, E. S.; Emadi, A. Ruthenium-Based Chemotherapeutics: Are They Ready for Prime Time? Cancer Chemother. Pharmacol. 2010, 66 (1), 1-9. https://doi.org/10.1007/s00280-010-1293-1.

(43) Gasser, G.; Ott, I.; Metzler-Nolte, N. Organometallic Anticancer Compounds. J. Med. Chem. 2011, 54 (1), 3-25. https://doi.org/10.1021/jm100020w.

(44) Muthná, D.; Tomšík, P.; Havelek, R.; Köhlerová, R.; Kasilingam,
V.; Cermáková, E.; Stíbal, D.; Rezáčová, M.; Süss-Fink, G. InVitro and in-Vivo Evaluation of the Anticancer Activity of Diruthenium-2, a New Trithiolato Arene Ruthenium Complex [(H6-p-MeC6H4Pri)2Ru2( $\mu-\mathrm{S}-\mathrm{p}-\mathrm{C} 6 \mathrm{H} 4 \mathrm{OH}) 3] \mathrm{Cl}$. Anticancer. $\begin{array}{llll}\text { Drugs } & \text { 2016, } & 27 & \text { (7), }\end{array}$ https://doi.org/10.1097/CAD.0000000000000374.

(45) Primasová, H.; Paul, L. E. H.; Diserens, G.; Primasová, E.; Vermathen, P.; Vermathen, M.; Furrer, J. 1H HR-MAS NMRBased Metabolomics of Cancer Cells in Response to Treatment with the Diruthenium Trithiolato Complex [(pMeC6H4iPr)2Ru2(SC6H4-p-But)3]+ (DiRu-1). Metabolites 2019, 9 (7), 146. https://doi.org/10.3390/metabo9070146.

(46) Stíbal, D.; Therrien, B.; Süss-Fink, G.; Nowak-Sliwinska, P.; Dyson, P. J.; Čermáková, E.; Řezáčová, M.; Tomšík, P. Chlorambucil Conjugates of Dinuclear P-Cymene Ruthenium Trithiolato Complexes: Synthesis, Characterization and Cytotoxicity Study in Vitro and in Vivo. J. Biol. Inorg. Chem. 2016, 21 (4), 443-452. https://doi.org/10.1007/s00775-0161353-z.

(47) Ibao, A. F.; Gras, M.; Therrien, B.; Süss-Fink, G.; Zava, O.; Dyson, P. J. Thiolato-Bridged Arene-Ruthenium Complexes: Synthesis, Molecular Structure, Reactivity, and Anticancer Activity of the Dinuclear Complexes [(Arene)2Ru2(SR)2Cl2]. Eur. J. Inorg. Chem. 2012, 2 (9), 1531-1535. https://doi.org/10.1002/ejic.201101057.

(48) Stíbal, D.; Therrien, B.; Giannini, F.; Paul, L. E. H.; Furrer, J. Süss-Fink, G. Monothiolato-Bridged Dinuclear Arene Ruthenium Complexes: The Missing Link in the Reaction of Arene Ruthenium Dichloride Dimers with Thiols. Eur. J. Inorg. Chem. 2014, $2014 \quad$ (34), 5925-5931. https://doi.org/10.1002/ejic.201402754.

(49) Stíbal, D.; Riedel, T.; Dyson, P. J.; Süss-Fink, G.; Therrien, B. Dinuclear Arene Ruthenium Thiolato Complexes with Fluorous Side-Chains. Inorganica Chim. Acta 2016, 444, 51-55. https://doi.org/10.1016/j.ica.2016.01.031.

(50) Hansch, C.; Leo, A.; Taft, R. W. A Survey of Hammett Substituent Constants and Resonance and Field Parameters. Chem. Rev. 1991, 91 (2), 165-195.

(51) Geiser, L.; Giannini, F.; Furrer, J. Unpublished Results.

(52) Eyring, H. The Activated Complex in Chemical Reactions; 1935; Vol. 3. https://doi.org/10.1063/1.1749604.

(53) Primasová, H.; Daepp, J.; Furrer, J. Synthesis of Previously Unreported Cationic Thiolato-Bridged Dinuclear Arene Ruthenium(II) Complexes of the Type [(H6-pMeC6H4Pri)2Ru2( $\mu$-SR)3]+ Using a Modified Synthetic Route. (Unpublished) 2019.

(54) Dynamics Center 2.5 .6 https://www.bruker.com/products/mr/nmr/software/dynamicscenter.html (accessed Nov 29, 2019).

(55) Akaike, H. BDD Representation for Incompletely Specified Multiple-Output Logic Functions and Its Applications to the Design of LUT Cascades. IEICE Trans. Fundam. Electron. Commun. Comput. Sci. 1974, 19 (6), 716-723. https://doi.org/10.1093/ietfec/e90-a.12.2762.

(56) Susanne, F.; Smith, D. S.; Codina, A. Kinetic Understanding Using NMR Reaction Profiling. Org. Process Res. Dev. 2012, 16 (1), 61-64. https://doi.org/10.1021/op200202k.

(57) Giannini, F.; Furrer, J.; Ibao, A. F.; Süss-Fink, G.; Therrien, B. Zava, O.; Baquie, M.; Dyson, P. J.; Štěpnička, P. Highly Cytotoxic Trithiophenolatodiruthenium Complexes of the Type [(H6-p-MeC6H4Pr i ) 2Ru2(SC6H4-p-X)3] +: Synthesis, Molecular Structure, Electrochemistry, Cytotoxicity, and Glutathione Oxidation Potential. J. Biol. Inorg. Chem. 2012, 17 (6), 951-960. https://doi.org/10.1007/s00775-012-0911-2.

(58) Revell, L. E.; Williamson, B. E. Why Are Some Reactions Slower at Higher Temperatures? J. Chem. Educ. 2013, 90 (8), 10241027.

(59) Hutter, J.; Iannuzzi, M.; Schiffmann, F.; Vandevondele, J. Cp2k: Atomistic Simulations of Condensed Matter Systems. Wiley Interdiscip. Rev. Comput. Mol. Sci. 2014, 4 (1), 15-25. https://doi.org/10.1002/wcms.1159.

(60) Lippert, G.; Hutter, J.; Parrinello, M. A Hybrid Gaussian and Plane Wave Density Functional Scheme. Mol. Phys. 1997, 92 (3), 
(61)

477-488. https://doi.org/10.1080/002689797170220.

Vandevondele, J.; Krack, M.; Mohamed, F.; Parrinello, M.; Chassaing, T.; Hutter, J. Quickstep: Fast and Accurate Density Functional Calculations Using a Mixed Gaussian and Plane Waves Approach. Comput. Phys. Commun. 2005, 167 (2), 103 128. https://doi.org/10.1016/j.cpc.2004.12.014.

Goedecker, S.; Teter, M.; Hutter, J. Http://Www.Interempresas.Net/MetalMecanica/Articulos/26079 -Conos-Porta-Herramientas-Para-Mecanizado-de-Alta-

Velocidad.Html. Phys. Rev. B 1996, 54 (3), 1703. https://doi.org/10.1103/PhysRevB.54.1703.

(63) Krack, M. Pseudopotentials for $\mathrm{H}$ to $\mathrm{Kr}$ Optimized for GradientCorrected Exchange-Correlation Functionals. Theor. Chem. Acc. 2005, 114 (1-3), 145-152. https://doi.org/10.1007/s00214-005$0655-\mathrm{y}$.

(64) VandeVondele, J.; Hutter, J. Gaussian Basis Sets for Accurate Calculations on Molecular Systems in Gas and Condensed Phases. J. Chem. Phys. 2007, 127 (11). https://doi.org/10.1063/1.2770708.

(65) A. D. Becke. Density-Fnnctional Exchange-Energy Approximation with Correct Asymptotic Behavior. Phys. Rev. A 1988, 4 (4), 276-282. https://doi.org/10.1063/1.1749835.

(66) Lee, C.; Yang, W.; Parr, R. G. Development of the Colle-Salvetti Correlation-Energy Formula into a Functional of the Electron Density. Phys. Rev. B 1988, 37, 785-789. https://doi.org/10.1016/0009-2614(89)85118-8
(67) Grimme, S.; Antony, J.; Ehrlich, S.; Krieg, H. A Consistent and Accurate $\mathrm{Ab}$ Initio Parametrization of Density Functional Dispersion Correction (DFT-D) for the 94 Elements H-Pu. $J$. Chem. Phys. 2010, 132 (15). https://doi.org/10.1063/1.3382344.

(68) Grimme, S.; Ehrlich, S.; Goerigk, L. Effect of the Damping Function in Dispersion Corrected Density Functional Theory. $J$. Comput. Chem. DOI 2011, 32 (7), 1456-1465. https://doi.org/10.1002/jcc.

(69) VandeVondele, J.; Hutter, J. An Efficient Orbital Transformation Method for Electronic Structure Calculations. J. Chem. Phys. 2003, 118 (10), 4365-4369. https://doi.org/10.1063/1.1543154.

(70) Henkelman, G.; Uberuaga, B. P.; Jónsson, H.; Henkelman, G. A Climbing Image Nudged Elastic Band Method for Finding Saddle Points and Minimum Energy Paths A Climbing Image Nudged Elastic Band Method for Finding Saddle Points and Minimum Energy Paths. J. Chem. Phys. 2011, 9901 (2000), 1-5. https://doi.org/10.1063/1.1329672.

(71) Andreussi, O.; Dabo, I.; Marzari, N. Revised Self-Consistent Continuum Solvation in Electronic-Structure Calculations. $J$. Chem. Phys. 2012, 136 (6). https://doi.org/10.1063/1.3676407.

(72) Riddick, J.; Bunger, W. Organic Solvents: Physical Properties and Methods of Purification, Band 2, 3rd ed.; Wiley-Interscience, 1970. 